\title{
Occurrence and High-Throughput Sequencing of Viruses in Ohio Wheat
}

\author{
B. A. Hodge, ${ }^{1}$ P. A. Paul, ${ }^{1}$ and L. R. Stewart ${ }^{1,2, \dagger}$ \\ ${ }^{1}$ Department of Plant Pathology, Ohio Agricultural Research and Development Center, The Ohio State University, Wooster, OH \\ 44691 \\ ${ }^{2}$ Corn, Soybean, and Wheat Quality Research Unit, U.S. Department of Agriculture Agricultural Research Service, Wooster, OH \\ 44691
}

\begin{abstract}
Ohio is a leading producer of soft red winter wheat in the United States. Many viruses impact wheat production, but there is a lack of contemporary information on the distribution and potential impact of wheat viruses in Ohio. To address this knowledge gap, we created a comprehensive dataset of viruses identified by high-throughput sequencing (HTS) and their incidence in field sites sampled across the state. Samples were collected from 103 field sites in surveys conducted in 2012, 2016, and 2017 and subjected to RNA HTS, reverse transcription (RT) PCR, or enzyme-linked immunosorbent assay to assess virus sequence diversity, prevalence, and incidence within fields. Partial and complete virus sequences were assembled and detection validated by RT-PCR. Assembled sequences were compared with previously known virus sequences, and novel sequences were validated by Sanger sequencing. The viruses detected most often included barley yellow dwarf virus (BYDV), cereal yellow dwarf virus (CYDV), wheat streak mosaic virus

fields where they were detected. Brome mosaic virus (BMV) and cocksfoot mottle virus (CfMV) were also viruses of potential importance detected in Ohio, found in 26 and $17 \%$ of the field sites sampled, respectively. Based on results from logistic regression analyses, the presence of BYDV, CYDV, WSMV, and WSSMV was associated with the presence of volunteer wheat, BYDV and CfMV with monocots as the previous crop, and BMV with the presence of nearby corn fields $(P<0.10)$. For six viruses, there was evidence of spatial clustering in at least one field site and the variance of mean incidence was higher at the county level than at the regional spatial level. This finding suggests that county- and site-specific factors influenced the incidence and spatial pattern of some viruses. The results of this study provide a snapshot of viruses present in Ohio wheat and insights into their biology, potential risks to wheat production, and possible management strategies.
\end{abstract} (WSMV), and wheat spindle streak mosaic virus (WSSMV). These viruses were detected at $67,69,55$, and $28 \%$ of the field sites sampled, with mean incidences of $18,19,20$, and $49 \%$, respectively, within
Keywords: cereals and grains, field crops, disease management, pathogen detection, pathogen diversity, viruses and viroids
Plant viruses are important, but often overlooked, pathogens of wheat (Triticum aestivum) globally (Almas et al. 2016; Budge et al. 2008; Lister and Ranieri 1995; Rotenberg et al. 2016; Velandia et al. 2010). Virus pathogens can limit wheat grain yield and quality (Byamukama et al. 2014; Choudhury et al. 2019; Cunfer et al. 1988) as well as straw yield (Byamukama et al. 2014), thus warranting attention. At a multistate level, virus diseases reduce wheat yield by an estimated average of 7 to 10\% annually (Brakke 1987; Hollandbeck et al. 2017), with some individual viruses such as wheat streak mosaic virus

${ }^{\dagger}$ Corresponding author: L. R. Stewart; lucy.stewart@ars.usda.gov

Funding: This work was funded by the Ohio Small Grains Marketing Program, the Ohio Agricultural Research and Development Center SEEDS industry grant program, the U.S. Department of Agriculture Agricultural Research Service, and The Ohio State University Department of Plant Pathology. Salaries and research support for B. A. Hodge and P. A. Paul were provided by state and federal funds to the Ohio Agricultural Research and Development Center. This research was supported in part by the U.S. Department of Agriculture Agricultural Research Service. Mention of trade names or commercial products in this publication is solely for the purpose of providing specific information and does not imply recommendation or endorsement by the U.S. Department of Agriculture. USDA is an equal opportunity provider and employer.

*The $\boldsymbol{e}$-Xtra logo stands for "electronic extra" and indicates that supplementary materials are published online.

The author(s) declare no conflict of interest.

Accepted for publication 8 January 2020 .

This article is in the public domain and not copyrightable. It may be freely reprinted with customary crediting of the source. The American Phytopathological Society, 2020.
(WSMV) capable of causing losses of up to $100 \%$ (Almas et al. 2016). Accurate identification of viruses and knowledge of their biology, prevalence, diversity, and distribution is crucial for effective management of the diseases they cause (Ordon et al. 2009).

In the United States, soft red winter wheat (SRWW), the class of wheat primarily used for cookies, cakes, and biscuits, is grown predominantly in the Midwest and Eastern half of the wheat belt. Ohio is one of the leading producers of SRWW in the country, with a total of 182,109 ha harvested in 2018 , contributing $\$ 170$ million to the state's economy (National Agricultural Statistics Service 2019). Most modern SRWW cultivars have the genetic potential to produce more than they actually yield most years (e.g., 2018 state average of 5.04 MT $\mathrm{ha}^{-1}$ ), attributable in part to diseases (Barker et al. 2017; Campbell and Lefever 1977; Green et al. 2012). Surveys for wheat viruses have been conducted in states producing hard red winter and spring wheat (Burrows et al. 2009; Rotenberg et al. 2016) and SRWW grown in New York (Miller et al. 1991) and Alabama (Bowen et al. 2003), but there is a lack of contemporary information on which viruses pose a threat to SRWW production in Ohio and other states in the Midwest. Historical reports, field observations, and diagnosis on field samples provide evidence that several viruses, including barley yellow dwarf virus (BYDV; Zambrano et al. 2016), WSMV (Stenger et al. 2002), Brome mosaic virus (BMV; Louie and Knoke 1991), and wheat spindle streak mosaic virus (WSSMV; Folke 1945) are present in the state; however, broad surveys for virus presence, distribution, diversity, and impact are lacking.

There are more than 50 virus species known to infect wheat worldwide (Ordon et al. 2009). Viruses that are considered of global economic importance owing to their intercontinental distribution and yield impact include BYDV (genus Luteovirus) and Cereal yellow dwarf virus (CYDV; genus Polerovirus), WSMV (genus Tritimovirus), Soilborne wheat mosaic virus (SBWMV; genus Furovirus), and WSSMV (genus Bymovirus) (Clover et al. 2001; Lister and Ranieri 1995; Miller and Rasochova 1997; Singh et al. 2018). These 
viruses are also widely distributed in the major wheat growing areas of the United States, including the Great Plains (Byamukama et al. 2013; Lommel et al. 1986; Rotenberg et al. 2016) and the Pacific Northwest (Bruehl and Keifer 1958; Halbert and Pike 1985; Hamm et al. 2007). BYDV-PAV and CYDV-RPV, both causal agents of barley yellow dwarf disease and transmitted by the bird cherry-oat aphid (Rhopalosiphum padi), have historically been the most prevalent wheat viruses in the United States (Bockus et al. 2001; Burrows et al. 2009; Rotenberg et al. 2016).

While viruses with global distributions are likely also present in Ohio, some viruses have distributions and economic impact localized to specific wheat growing regions of the United States or market classes. For example, Triticum mosaic virus and High Plains wheat mosaic virus (HPWMoV) cause significant economic damage in the Great Plains region, especially in coinfections with WSMV (Byamukama et al. 2013, 2016; Rotenberg et al. 2016). Virus biology may in part influence differences in prevalence and distribution between and within fields, multistate production regions, and grain market classes. For instance, since WSSMV and SBWMV, soilborne viruses transmitted by the plasmodiophorid Polymyxa graminis (Rao and Brakke 1969; Slykhuis and Barr 1978), require cool, wet field conditions with optimum temperatures between 17 and $24^{\circ} \mathrm{C}$ for disease to develop (Himmel et al. 1992; Ohsato et al. 2003; Slykhuis 1970), these viruses often cause economic losses primarily in winter wheat production regions.

The lack of current information on viruses potentially impacting Ohio wheat highlights the need for more systematic and comprehensive surveys using contemporary approaches. Estimates of virus prevalence, incidence and severity within fields, and sequence diversity are all important for disease risk assessment and management. For instance, sequence diversity can be important for identifying dominant viruses and strains, detecting potential resistancebreaking isolates, and characterizing novel viruses (Maliogka et al. 2018; Montarry et al. 2011; Villamor et al. 2019). The assessment of sequence diversity of viruses in environmental samples using metagenomic analysis is now more accessible as high-throughput

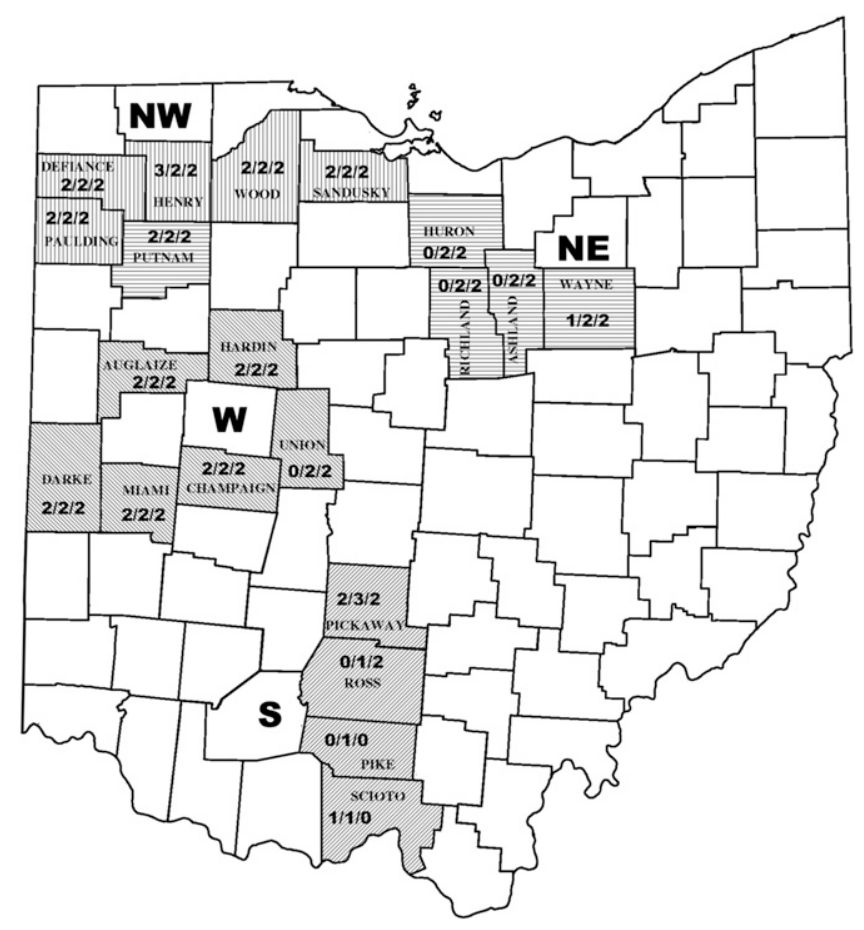

Fig. 1. A map of Ohio depicting counties that were surveyed for wheat viruses. The targeted counties are grouped into four wheat growing regions: the Northwest (NW), Northeast (NE), Western (W), and Southern (S) regions. The number of field sites (unique geographical sampling area that included a cultivated wheat field and/ or nearby volunteer wheat field) in these counties in 2012, 2016, and 2017 is listed in order by year within each county. sequencing (HTS) has become more affordable. Metagenomic analysis using HTS is an effective approach for identifying novel as well as known viruses (reviewed in Dutilh et al. 2017; Villamor et al. 2019) and their previously unknown as well as known virus genome components, as for the multisegmented HPWMoV (Stewart 2016; Tatineni et al. 2014).

The objectives of this study were as follows: (i) to identify and assess the diversity of virus sequences present in wheat fields of Ohio, (ii) to estimate virus prevalence and incidence and determine in-field distribution patterns of a subset of viruses, and (iii) to quantify associations between field site-specific factors and the presence of the most prevalent viruses. To accomplish these objectives, we collected wheat samples and associated metadata from field sites across Ohio and used a combination of HTS, reverse transcription (RT) PCR, and enzyme-linked immunosorbent assay (ELISA) for virus identification, characterization, and quantification; and we then fit meta-analytic and logistic regression models to assess the spatial heterogeneity or clustering of a subset of viruses and to quantify associations among their presence and field site-specific factors.

\section{Materials and Methods}

Overview of sample collection, handling, and processing. Symptomatic plant samples for RNA HTS and RT-PCR. In March and April of 2012, 2016, and 2017, 15 to 20 samples of SRWW exhibiting typical virus symptoms such as stunting, mosaic, chlorosis, or striping were collected between Feekes growth stages 3 and 5 from wheat fields in Ohio (Large 1954). A total of 103 field sites (27 in 2012, 40 in 2016, and 36 in 2017; Fig. 1) were sampled. A field site represented a specific geospatial sampling area (Supplementary Table S1), which consisted of a cultivated wheat field, a volunteer wheat field, or the two in an adjacent pair. Each year, the same 17 to 20 counties were surveyed, with two field sites typically selected per county based on the presence of virus-like symptoms, proximity to volunteer wheat, and distance from other field sites. Individual samples, consisting of a single whole plant dug out with soil or a cluster of plants with similar symptoms, were placed in pots or bags and labeled with field site information. If no symptoms were observed at a field site, then samples were collected arbitrarily in and near the edge of the field. All samples were maintained at ambient temperature or in coolers during transit and were then stored at $10^{\circ} \mathrm{C}$ until processed. Leaves were removed and grouped by field site based on similar symptoms (chlorotic wheat, wheat with mosaic, and asymptomatic wheat). For 2012, a fourth sample category, a composite of weedy grasses from with the field site and from the outside edges of field with potential virus symptoms, was collected; for 2016 and 2017, the fourth category was wheat with "other" potential symptoms encompassing any potential symptoms besides mosaic and chlorosis (e.g., stunting). Samples were aliquoted into microfuge tubes and ELISA bags and stored at $-80^{\circ} \mathrm{C}$ within $24 \mathrm{~h}$ of collection.

Transect sampling. In 2016 and 2017, whole-leaf samples were collected at regular intervals along line transects in cultivated wheat fields without any symptom or other selection, and the samples were then tested for individual viruses to estimate incidence (percentage of samples in which each virus was detected along a transect). Transect samples were collected within cultivated wheat fields located at a subset of the 2016 to 2017 field sites with a total of 72 unique year $x$ field combinations. Sampling was done using a method modified from that described in Basu et al. (1977): a transect was run diagonally across each field from corner to corner, and samples were collected at 20 equidistant points (6 to $12 \mathrm{~m}$, depending on field size) along the transect. At each sampling point, 10 to 15 leaves from several tillers were collected within a $0.1-\mathrm{m}$ length of row and pooled to form a composite sample. Samples were stored on ice or at $4^{\circ} \mathrm{C}$ until subdivided into 1-g aliquots of whole-leaf samples and stored at $-80^{\circ} \mathrm{C}$. For both types of samples, field site-specific metadata were recorded, including presence/absence of adjacent volunteer wheat, presence/absence of corn (Zea mays) residue in an adjacent field (indicative of corn being the previous crop in that field), and the predominant and distinguishable type of crop residue present in the wheat field being sampled (corn, another monocot, or soybean). 
Virion preparation for HPWMoV. HPWMoV has an unusually large number of genome segments (eight to nine) (Tatineni et al. 2014) and proposed variability in genome segment number across isolates (Stewart 2016). To enrich virus sequences in order to obtain a complete genome sequence of Ohio HPWMoV, a virion preparation was conducted as previously described (Louie et al. 2006; Shepherd et al. 1987) on symptomatic samples collected from a volunteer wheat field in 2016 from the Northwest Ohio Agricultural Research and Development Branch in Custar, Ohio, in which HPWMoV was detected. RNA was extracted from the virion preparation as described below and used for HTS.

HTS analysis of symptomatic wheat tissue. Total RNA extraction and library construction. Plant samples collected based on symptoms from the 2012, 2016, and 2017 surveys and the HPWMoV virion preparation were subjected to total RNA extraction using a Directzol RNA MiniPrep Kit (Zymo Research, Irvine, CA) following the manufacturer's protocol. RNA was similarly extracted from frozen $\left(-80^{\circ} \mathrm{C}\right)$ wheat samples with HPWMoV from Michigan (courtesy of William Dolezol) and from Idaho (courtesy of Dallas Seifers) to compare sequences with those of the Ohio HPWMoV isolates. RNA from the 2012 and 2016 surveys was used for HTS. For the 2012 survey, RNA from plants in each of the symptom categories (four categories per field site) from 27 field sites was pooled in equimolar amounts as previously described (Stewart et al. 2014). The library was then prepared and sequenced without multiplexing, as described previously (Stewart et al. 2014), such that no barcodes distinguished individual or subgroups of sequences by origin. For the 2016 and 2017 surveys, RNA from the four symptom categories per field site was pooled in equimolar amounts into composite samples termed superpools, each representing all of the symptomselected samples from a single field site. cDNA libraries were generated for the 2016 RNA superpools, in which each was separately barcoded to distinguish field site origin, using the TrueSeq Stranded Total RNA with Ribo-Zero Plant kit (Illumina, San Diego, CA) according the manufacturer's protocol. Two multiplex libraries were prepared from 2016 samples, one containing cDNA from 22 superpools and another containing cDNA from 21 superpools that included the cDNA from the remaining 18 field sites plus the Ohio HPWMoV virion preparation library and the HPWMoV samples from Michigan and Idaho. These two multiplexed libraries were then sequenced on two lanes of a Dual-Lane Flow Cell using the Illumina HiSeq 2500 platform, Rapid output mode, at the Ohio State University Comprehensive Cancer Center to obtain 100-nt paired-end reads. Raw reads from both 2012 and 2016 were deposited into the NCBI Sequence Read Archive database (accession PRJNA558380).

HTS analysis pipeline. HTS bioinformatic analyses were carried out using CLC Genomics Workbench (version 8.1.1; Qiagen, Redwood City, CA) following a pipeline similar to that previously described (Stewart et al. 2014), with the 2012 sample set and each of the 43 multiplexed pooled samples from 2016 analyzed separately. Following trimming for quality, poly(A) tails, and adapter sequences, reads mapping to the wheat genome (Assembly TGAC1, Earlham Institute; parameters listed in Supplementary Data File S1) (Mayer et al. 2014) were subtracted. The remaining reads were de novo assembled using default parameters (listed in Supplementary Data File S1). A custom plant virus database was prepared by downloading all virus sequences from NCBI on 16 March 2018 and removing all sequences larger than $20 \mathrm{~kb}$ and those with names unrelated to plant viruses. This database was then used to select putative virus sequence contigs for the analysis pipeline as previously described (Stewart et al. 2014). De novo assembled contigs for both 2012 and 2016 were combined into one dataset and manually assembled in Sequencher (GeneCodes Corp., Ann Arbor, MI) into contigs of contigs (termed supercontigs) in order to obtain full-length and near-full-length virus sequences. Supercontigs were assembled in Sequencher using the following parameters: automatic assembly, large gaps algorithm, $50 \mathrm{nt}$ overlap, and $90 \%$ similarity between contigs (95\% similarity for BYDV/CYDV and WSSMV assemblies). For HPWMoV sequences, the same parameters were used with the "assemble interactively" setting in Sequencher. The consensus sequences were extracted from each supercontig using the most frequent base-call algorithm. The consensus sequences of supercontigs were searched against the NCBI megablast nr database, and sequences identified as nonvirus were discarded. All reads from both 2012 and 2016 were then mapped back to the consensus sequences using CLC Genomics Workbench (version 12.0.3; Qiagen) using the "map reads to contigs" tool (parameters listed in Supplementary Data File S1). Only Sanger-validated sequences were deposited in GenBank, annotated based on type isolate sequences for each respective species using MacVector (MacVector Inc., Apex, NC).

Sanger sequencing to confirm novel or outlier virus sequences. Coat protein sequences of BYDV (corresponding to nt 2,858 to 3,460 of BYDV-PAV type isolate X07653 and BYDV-PAS type isolate L25299) and CYDV (corresponding to nt 3,745 to 4,359 of CYDV-RPV type isolate L25299 and nt 3,632 to 4,246 of CYDVRPS type isolate AF235168) were amplified from 2016 superpools from which BYDV and CYDV supercontigs were generated using a previously described two-step RT-PCR protocol (Hodge et al. 2019), with primers ShuF/YanR for BYDV (Malmstrom and Shu 2004) and BAH 85/86 for CYDV. PCR products of approximately $900 \mathrm{bp}$ were cut and purified from $2 \%$ agarose gels using a Monarch DNA gel extraction kit (New England Biolabs, Ipswich, MA), and aliquots of purified PCR products were test digested using $B g l$ II restriction enzyme (New England Biolabs) to distinguish BYDV-PAV from BYDV-PAS and CYDV-RPV from CYDV-RPS and ensure recovery of clones representing each of the observed variants. Intact purified PCR products representing all restriction patterns were ligated into the pMiniT vector (New England Biolabs) and then Sanger sequenced from recovered plasmids using the included vector primers. Partial sequences of a potential novel variant of BYDV-PAS (BYDV-PAS OH2) and a potential variant of WSSMV (WSSMV$\mathrm{OH} 2)$ RNA 1 were confirmed by RT-PCR as previously described (Hodge et al. 2019) and direct Sanger sequencing of the products. The sequences of these isolates were each amplified from single field-site RNA samples from 2016 (from Union County for BYDV-PAS OH2; from Champaign County for WSSMV-OH2). Both $5^{\prime}$ and $3^{\prime}$ rapid amplification of cDNA ends (RACE) and sequencing were conducted as previously described (Green and Sambrook 2012), using sequence-specific primers to determine and validate authentic virus end sequences. Sanger sequences were compared with supercontigs of each respective assembly.

Phylogenetic analysis of BYDV coat protein. All BYDV coat protein nucleotide sequences between 599 and 604 nt were downloaded from GenBank and aligned with the Sanger sequenced coat protein sequences of BYDV in MacVector using the MUSCLE alignment program. Nonredundant sequences were then analyzed using the "RAxML-HPC v.8 on XSEDE" tool (Stamatakis 2014) in the CIPRES Science Gateway website (Miller et al. 2010). A general time reversal substitution model with a gamma distribution and a rapid bootstrap analysis with 1,000 bootstrap replicates were used to find the best scoring maximum likelihood tree.

Virus detection at each field site. For symptomatic samples, individual RNA samples and pooled sets from 2012, 2016, and 2017 were subjected to RT-PCR to test for specific viruses, based on the HTS results. One-step RT-PCR was performed as previously described (Stewart et al. 2014) using virus-specific primers and annealing temperatures (Supplementary Table S2). The primers that were used targeted viruses at the species level, with the exception of primers used to specifically target BYDV-PAS OH2 and WSSMV$\mathrm{OH} 2$, which differentiated these from sequence variants of BYDVPAS and WSSMV within the sample set. For transect samples, double antibody sandwich (DAS) ELISAs (Voller et al. 1978) from Agdia Inc. (Elkhart, IN) were used to detect BYDV-PAV, CYDVRPV, WSMV, BMV, WSSMV, SBWMV, and HPWMoV following the manufacturer's guidelines. Virus presence was determined by comparing changes in absorbance values to a healthy control, based on four criteria as previously described (Hodge et al. 2019; Todd et al. 2010): (i) the rate of change in average absorbance value at $405 \mathrm{~nm}$ per minute was at least twice that of the healthy control, (ii) the average absorbance value at $405 \mathrm{~nm}$ was greater than or equal 
to the average absorbance value of the healthy control plus three times the standard deviation of the healthy control, (iii) the average absorbance value at $405 \mathrm{~nm}$ was at least twice the average absorbance value of the healthy control, and (iv) the average absorbance value at $405 \mathrm{~nm}$ was greater than or equal to the positive control. A virus was considered detected within a sample if any two of these four criteria were met.

Analysis of field site diagnostic and transect data. Associations among virus presence and field site-specific factors. Associations between the presence of specific viruses at each field site and adjacent volunteer wheat fields (coded 1 if present and 0 otherwise), previous crop (coded 1 if corn, wheat, barley, or rye and 0 if soybean), or adjacent corn fields (coded 1 if present and 0 if not) for that field site were analyzed using binary logistic regression as previously described (Simon et al. 2018a). Separate models were fitted to the data for each virus using PROC LOGISTIC in SAS version 9.4 (SAS Inc., Cary, NC) with maximum likelihood as the estimation method (Allison 2012; Derr 2013; Paul and Munkvold 2004; Simon et al. 2018a). The absence of adjacent volunteer wheat fields, the absence of a nearby corn field, and soybean as the previous crop were used as reference factor levels to test the hypothesis that the presence of adjacent volunteer wheat fields, adjacent corn fields, or a monocot as the previous crop was associated with virus presence. Viruses that were detected at fewer than 10 total field sites across the three surveys were not included in the analysis. A backward stepwise variable selection option was included as part of the model statement to eliminate variables with $P \geq 0.20$. Odds ratios were estimated and reported only for factors with statistically significant associations with virus presence at $P \leq 0.10$.

Heterogeneity of plant virus incidence at two spatial scales. For the viruses tested for by DAS-ELISA in the transect samples, incidence (number of samples in which the virus was detected divided
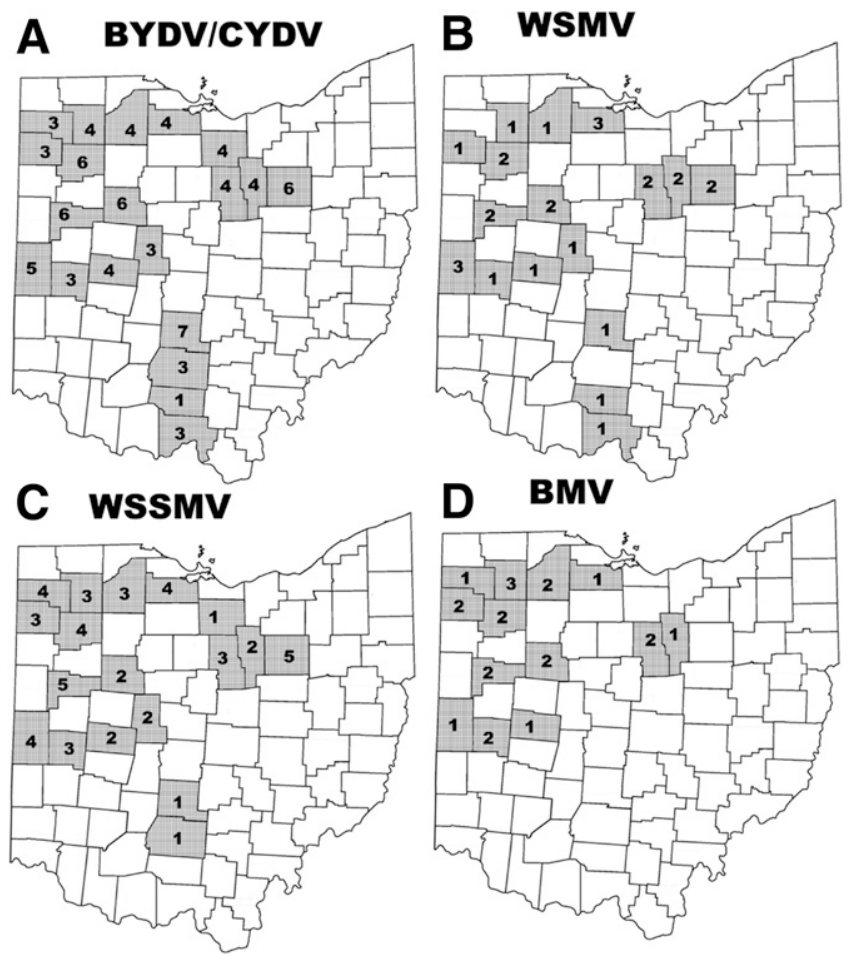

Fig. 2. Number of field sites (unique geographical sampling area that included a cultivated wheat field and/or nearby volunteer wheat field) and counties in Ohio in which the following viruses were detected through reverse transcription PCR in 2012, 2016, and 2017: A, barley yellow dwarf virus (BYDV) or cereal yellow dwarf virus (CYDV), B, wheat streak mosaic virus (WSMV), C, wheat spindle streak mosaic virus (WSSMV), and D, Brome mosaic virus (BMV). Counties are shaded if the virus was detected in at least one site in 2012, 2016, or 2017, with the total number of positive sites across the 3 survey years listed in the respective county. All isolates/species of BYDV and CYDV are represented together in A, and all isolates of WSSMV are represented in C. by 20 , the number of samples collected per transect) was used to estimate variability for each virus at region and county spatial scales. Four Ohio wheat growing regions were defined based on the field sites of the counties from which samples were collected (Fig. 1). Incidence data from 2016 and 2017 were pooled and analyzed as a single dataset, and variability at the two spatial scales was estimated by fitting generalized linear mixed models (Gbur et al. 2012; Kriss et al. 2012; Simon et al. 2018b; Stroup 2013), with each cultivated field (transect) considered a sampling unit. For each of the detected viruses (BYDV-PAV, CYDV-RPV, BMV, WSMV, WSSMV, SBWMV, HPWMoV), variances were estimated for the random effects of wheat growing region $(R)$ and county within wheat growing region (C) using PROC GLIMMIX in SAS, assuming a conditional binomial distribution as previously described (Simon et al. 2018b).

Estimation of spatial clustering of viruses within wheat fields. Ordinary runs analyses were conducted on transect data for each virus as described in Madden et al. (1982) to assess spatial patterns at the field level. Following Madden et al. (1982) and Elliott and Wartenberg (2004), spatial clustering was defined as an aggregation of virus-positive samples, in contrast to nonaggregation where the virus was considered randomly distributed within the transect. As described by Madden et al. (1982), based on the work of Gibbons (1976), "In an ordered sequence of some two types of symbols [0 and 1 for instance], a run is defined as a succession of one or more identical symbols, which are followed and preceded by a different symbol or no symbol at all." For example, in a cultivated field in Miami County, WSSMV was detected in 5 of 20 samples collected along the transect in the following pattern: 00000000000000011111 (with $0=$ virus not detected and $1=$ virus detected). This transect has two ordinary runs: "0 00000000000000 " and "1 1111 " (i.e., two strings of the same symbol). For each transect by virus combination, the number of ordinary runs was calculated, and tables (Swed and Eisenhart 1943) were then used to determine whether the calculated number was significantly different from the expected number under the null hypothesis of randomness. To formally test this hypothesis, metaanalyses (Borenstein et al. 2009) were conducted using the individual $P$ values to test the global significance at $\alpha=5 \%$ of the outcome for each virus. The Fisher method (Borenstein et al. 2009) was used for this analysis. Using the $\chi^{2}$ test statistic with $2 k$ degrees of freedom (where $k$ is the number of $P$ values being combined), the global $P$ values were computed using a macro in SAS (L. V. Madden, unpublished data). A global $P$ value (significance level) of $<0.05$ was considered evidence of spatial clustering.

\section{Results}

Metagenomic analysis of symptomatic samples. Metagenomic analysis was conducted on $100 \mathrm{nt}$ reads generated by HTS of the symptomatic tissues collected in 2012 and 2016. After trimming and subtracting reads mapping to the wheat genome, the remaining 11.4 million reads (2012) and 46.4 million reads (2016) were de novo assembled into contigs using CLC Genomics Workbench. From the 2012 survey, 492,000 contigs were generated, with average length of $301 \mathrm{nt}$; from the 2016 survey, a total of 135,000 contigs were generated, with average length of $402 \mathrm{nt}$. Following removal of plant and other nonvirus contigs, a total of 2,167 de novo assembled contigs from both surveys were assembled into supercontigs using Sequencher. After sequence analyses and confirmation by RTPCR, sequences of 12 viruses were identified: BYDV-PAV, BYDV-PAS, CYDV-RPV, CYDV-RPS, WSMV, BMV, WSSMV, SBWMV, HPWMoV, oat necrotic mottle virus (ONMV), cocksfoot mottle virus (CfMV), and Agropyron mosaic virus (AgMV). The most prevalent viruses in each survey year were members of the family Luteoviridae, primarily BYDV-PAV and CYDV-RPV (Fig. 2A; Table 1). WSMV, WSSMV, and BMV were also highly prevalent in at least one survey year (Fig. 2B, C, and D; Table 1). SBWMV, HPWMoV, and ONMV were detected infrequently compared with the other viruses (Table 1). AgMV and CfMV were first detected in Ohio in 2016, as previously reported (Hodge et al. 2018a, b). CfMV, but not AgMV, was again detected in 2017 (Table 1). 
Virus prevalence and sequence diversity in Ohio. RT-PCR on symptom-selected samples was used to determine virus prevalence (percentage of sites from which a virus was detected), which is reported for each virus by year in Table 1 . Luteovirids were the most prevalent, found in the most field sites consistently across years. BYDV-PAV was detected in 63 to $68 \%$ of field sites across the 3 years, whereas CYDV-RPV was detected in 22 to $94 \%$ of the sites. BYDV-PAS $\mathrm{OH} 2$ and CYDV-RPS were rarer luteovirids, being detected in 0 to $5 \%$ and 0 to $19 \%$ of the field sites, respectively. WSSMV was consistently also prevalent, with the WSSMV-OH1 variant detected at 26 to $70 \%$ of the sites and the rarer variant WSSMV-OH 2 detected at 0 to $17 \%$ of the field sites. The prevalence of WSMV and BMV fluctuated across years, ranging from 7 to $50 \%$ and 15 to $59 \%$, respectively. HPWMoV, SBWMV, and ONMV were the least prevalent viruses in the survey, being detected at fewer than $11 \%$ of sites each year. As previously reported by Hodge et al. (2018a, b), CfMV and AgMV were initially detected in 2016, and CfMV was detected at $44 \%$ of the field sites in 2017 (Table 1).

Sequence analyses of highly prevalent viruses: BYDV and CYDV. Contigs de novo assembled in CLC Genomics Workbench that matched BYDV sequences from all sites/years were further assembled in Sequencher into four supercontigs, the consensus sequences of which were deposited in GenBank as BYDV-PAV OH1 (MN128941), BYDV-PAS OH1 (MN128938), BYDV-PAS OH2 (MN128939), and BYDV-PAS OH3 (MN128940) (Table 2). The BYDV-PAV OH1 consensus sequence shared $92.8 \%$ nucleotide identity with the BYDV-PAV type isolate (X07653; Table 2), whereas BYDV-PAS OH1, BYDV-PAS OH2, and BYDV-PAS OH3 consensus sequences shared 98.9, 89.6, and 95.4\% nucleotide identity with the BYDV-PAS type isolate (AF218798; Table 2). BYDV-PAS OH2 and BYDV-PAS OH3 shared 86.2 and $90.2 \%$ nucleotide identity with BYDV-PAS OH1, respectively. Notably, because of the dissimilarity of BYDV-PAV $\mathrm{OH} 2$ to other known BYDV isolates, the coat protein and part of whole genome were confirmed by Sanger sequencing from a single RNA sample in which the virus was detected, including $5^{\prime}$ and $3^{\prime}$ RACE (Supplementary Fig. S1).

The coat proteins of these four supercontig variants were confirmed by Sanger sequencing from individual fields (superpools), and they were deposited in GenBank as BYDV-PAV OH1A-C (MK913611 to MK913613), BYDV-PAS OH1A-F (MK913614 to MK913619), BYDV-PAS OH2A (MN128939), and BYDV-PAS OH3A (MK913620). The confirmed coat protein sequences from individual samples of BYDV-PAV and BYDV-PAS followed a similar pattern of nucleotide identity to that observed for the consensus fulllength assemblies. The three BYDV-PAV isolates shared 94 to $95 \%$ nucleotide identity and 96 to $99 \%$ amino acid identity with the BYDV-PAV type isolate (X07653.1; Supplementary Table S3). The BYDV-PAS OH1, BYDV-PAS OH2, and BYDV-PAS OH3 variants shared 98 to $99,92.8$, and $96.1 \%$ nucleotide identity and 97 to $99.5,89.5$, and $95 \%$ amino acid identity to the BYDV-PAS type isolate, respectively (Supplementary Table S3). A maximum likelihood phylogenetic tree was generated using the coat protein nucleotide sequences of the BYDV-Ohio variants, BYDV type isolates of BYDV-PAV, BYDV-PAS, and BYDV-MAV, and coat protein sequences of BYDV isolates from GenBank (Fig. 3) and deposited into TreeBase (S25227). BYDV-PAV OH1A-C variants clustered with the BYDV-PAV type isolate into a larger clade, separate from BYDV-MAV and BYDV-PAS. Within the BYDV-PAV clade, Ohio variants clustered together in a subclade with other BYDV-PAV isolates. A well-supported large BYDV-PAS clade included the type isolate and two subclades, one with BYDV-PAS OH1A-F variants and one with the BYDV-PAS type isolate. BYDV-PAS OH3 clustered with other isolates in a more distant subclade. BYDV-PAS $\mathrm{OH} 2$ did not cluster with either the BYDV-PAS or BYDV-PAV type isolates but fell between the two larger clades, along with some other BYDV-PAV isolates from Germany, Pakistan, and Turkey.

CYDV contigs assembled into two supercontig consensus sequences, deposited in GenBank as CYDV-RPV OH1 (MN241034) and CYDV-RPS OH1 (MK975889). CYDV-RPS-OH1 shared 82.4\% nucleotide identity with the CYDV-RPS type isolate (AF235168) from Mexico (Table 2), but notably shared high nucleotide identity $(97.4 \%)$ to the previously described CYDV-RPS-MI isolate (KY623680) from Michigan (Malmstrom et al. 2017). CYDV-RPV OH1 shared 98.9\% nucleotide identity with the CYDV-RPV type isolate (L25299; Table 2). The confirmed coat protein sequences were deposited in GenBank as CYDV-RPV OH1A-K (MK923569-MK923579) and CYDV-RPS OH1A (MK923580). The CYDV-RPS-OH1 coat protein sequence shared $82 \%$ nucleotide and $79 \%$ amino acid identity (Supplementary Table S3) with the type isolate (AF235168). The CYDV-PRV $\mathrm{OH} 1$ coat protein sequenced shared 98 to $99 \%$ nucleotide identity and 97 to $99 \%$ amino acid identity with the type isolate (L25299.1; Supplementary Table S3).

One of the current criteria for defining species for both the Luteovirus and Polerovirus genera is that an amino acid sequence of any gene product that is $<90 \%$ identical represents a new species (International Committee on Taxonomy of Viruses 2011). Based on their coat protein sequences, this criterion was met for both BYDV-PAS $\mathrm{OH} 2$ and CYDV-RPS $\mathrm{OH} 1$ when compared with the type isolates in their respective genera (Supplementary Table S4). In addition, the BYDV-PAS OH 2 coat protein shared $83.5 \%$ amino acid identity with the BYDV-PAV type isolate coat protein (CAA30493). The other protein products for BYDV-PAS $\mathrm{OH} 2$ shared from 88.3 to 93.6\% amino acid identity to their respective proteins of the BYDV-PAS type isolate (AF218798) except for P6, which shared $51.3 \%$ amino acid identity. The protein products for CYDV-RPS OH1 ranged from 67.7 to $84.1 \%$ amino acid identity to their respective protein products of the CYDV-RPS type isolate (AF235168).

Sequence analyses of prevalent viruses: WSMV and WSSMV. The WSMV supercontig shared $98 \%$ nucleotide identity with the WSMV type isolate (AF285169.1) and was deposited in GenBank as WSMV-OH1 (MK975887; Table 2). Four supercontigs, representing the bipartite genome of two distinct Ohio variants of WSSMV, were deposited in GenBank as WSSMV-OH1 RNA 1 (MN046367),

Table 1. Percentage of field sites (unique geographical sampling area that included a cultivated wheat field and/or nearby volunteer wheat field) in which each virus was detected (prevalence) in the 2012, 2016, and 2017 surveys by enzyme-linked immunosorbent assay or reverse transcription PCR

\begin{tabular}{lccc}
\hline & \multicolumn{3}{c}{ Survey year $^{\mathbf{b}}$} \\
\cline { 2 - 4 } Virus $^{\mathbf{a}}$ & $\mathbf{2 0 1 2}$ & $\mathbf{2 0 1 6}$ & $\mathbf{2 0 1 7}$ \\
\hline AgMV & $0(0 / 27)$ & $8(3 / 40)$ & $0(0 / 36)$ \\
BMV & $59(16 / 27)$ & $15(6 / 40)$ & $20(7 / 36)$ \\
BYDV-PAS & $15(4 / 27)$ & $13(5 / 40)$ & $20(7 / 36)$ \\
BYDV-PAV & $63(17 / 27)$ & $68(27 / 40)$ & $67(24 / 36)$ \\
BYDV-PAS OH2 & $0(0 / 27)$ & $5(2 / 40)$ & $3(1 / 36)$ \\
CfMV & $0(0 / 27)$ & $5(2 / 40)$ & $44(16 / 36)$ \\
CYDV-RPV & $22(6 / 27)$ & $80(32 / 40)$ & $94(34 / 36)$ \\
CYDV-RPS & $0(0 / 27)$ & $5(2 / 40)$ & $19(7 / 36)$ \\
HPWMoV & $11(3 / 27)$ & $5(2 / 40)$ & $3(1 / 36)$ \\
ONMV & $4(1 / 27)$ & $0(0 / 40)$ & $0(0 / 36)$ \\
SBWMV & $7(2 / 27)$ & $3(1 / 40)$ & $3(1 / 36)$ \\
WSMV & $7(2 / 27)$ & $50(20 / 40)$ & $22(8 / 36)$ \\
WSSMV-OH1 & $26(7 / 27)$ & $70(28 / 40)$ & $61(22 / 36)$ \\
WSSMV-OH2 & $0(0 / 27)$ & $5(2 / 40)$ & $17(6 / 36)$ \\
\hline
\end{tabular}

a Virus names are as follows: Agropyron mosaic virus (AgMV), Brome mosaic virus (BMV), barley yellow dwarf virus PAS and PAV (BYDV-PAS and BYDV-PAV), cocksfoot mottle virus (CfMV), cereal yellow dwarf virus RPV and RPS (CYDV-RPV and CYDV-RPS), High Plains wheat mosaic virus (HPWMoV), oat necrotic mottle virus (ONMV), soilborne wheat mosaic virus (SBWMV), wheat streak mosaic virus (WSMV), and wheat spindle streak mosaic virus (WSSMV; two Ohio isolates, $\mathrm{OH} 1$ and $\mathrm{OH} 2$ ).

$\mathrm{b}$ Percentages were estimated by dividing the number of field sites in which the specific virus was detected by the total number of field sites surveyed in each year (27, 40, and 36 in 2012, 2016, and 2017, respectively) multiplied by 100 .

c The prevalence of BYDV-PAS OH2 was determined using $\mathrm{OH} 2$-specific primers that did not detect other BYDV-PAS members, whereas the prevalence of all other BYDV-PAS variants was grouped under BYDV-PAS owing to the use of species primers that did not detect $\mathrm{OH} 2$. 
WSSMV-OH1 RNA 2 (MN046368), WSSMV-OH2 RNA 1 (MN046369), and WSSMV-OH2 RNA 2 (MN046370). The WSSMV-OH1 RNA 1 and RNA 2 sequences shared 99.2 and $94.2 \%$ nucleotide identity to the WSSMV Center isolate RNA 1 and RNA 2 sequences, respectively (MH645041 and MH654044), from France (Table 2). The WSSMV-OH2 RNA 1 and RNA 2 shared 93.4 and 90.3\% nucleotide identity, respectively, to the WSSMV Center isolate RNA 1 and RNA 2 sequences (MH645041 and MH654044). As noted earlier, discriminant primers were used to determine the prevalence of WSSMV-OH1 versus $\mathrm{OH} 2$, by which WSSMV-OH1 was found to be the more prevalent variant.

BMV RNA 1, 2, and 3 supercontigs shared $>99 \%$ nucleotide identity to a previously described Ohio BMV isolate (MH025765-67). Notably, all amino acid sequences shared $100 \%$ identity between $\mathrm{BMV}-\mathrm{OH} 1$ and BMV-OH2. The individual contigs from all three RNAs shared 98 to $99 \%$ nucleotide identity to the BMV type isolate sequence (RNA 1 = X02380.1, RNA 2 = X01678, and RNA 3 = J02042).
Low prevalence viruses. Two strains of HPWMoV were found in the surveys, both previously detected in Ohio (Stewart 2016; Stewart et al. 2013). One strain is more similar to the Nebraska type isolate ("Nebraska-like") and another, which has so far only been described in Ohio ("Ohio-like"), diverges by 10 to $20 \%$ nucleotide sequence identity and the number of NP segments detected (RNAs 3A and $3 \mathrm{~B}$ in the Nebraska-like but only one RNA3 in the Ohio-like). From our surveys, nine supercontigs were assembled with similarity to RNA segments of HPWMoV Nebraska-like isolates and deposited in GenBank as HPWMoV NWB1 (MN250337 to MN250344; MN311483). These represented near-complete sequences of RNA 2, 3A, 3B, 6, 7, and 8 and only partial sequences of RNA 1, 5, and 6 . From the Idaho sample, nine supercontigs represented all genome segments: near-complete sequences of RNA 1, 2, 3A, 4, 5, 6, 7, 8 and a partial sequence of RNA 3B (MN250358 to MN250363, MN311486, MN315261). From the Michigan sample, nine supercontigs were assembled, also representing all genome segments:

Table 2. Characterization of consensus sequences of viruses that were identified by RNA sequencing of symptomatic samples from the 2012 and 2016 surveys

\begin{tabular}{|c|c|c|c|c|c|c|}
\hline Ohio $(\mathrm{OH})$ sequence $^{\mathrm{a}}$ & Consensus accession $^{\mathbf{b}}$ & $\mathbf{R P K}^{\mathrm{c}}$ & Contigs $(n)^{\mathrm{d}}$ & Type species accession ${ }^{\mathrm{e}}$ & Coverage $(\%)^{\mathrm{f}}$ & Nucleotide identity $(\%)^{\mathrm{g}}$ \\
\hline BYDV-PAV OH1 & MN128941 & $9.4 \times 10^{4}$ & 172 & X07653 & 99.8 & 92.8 \\
\hline BYDV-PAS OH1 & MN128938 & $2.8 \times 10^{4}$ & 67 & AF218798 & 97.8 & 97.4 \\
\hline BYDV-PAS OH2 & MN128939 & $1.6 \times 10^{4}$ & 34 & AF218798 & 100 & 89.6 \\
\hline BYDV-PAS OH3 & MN128940 & $1.4 \times 10^{4}$ & 45 & AF218798 & 93.4 & 95.4 \\
\hline CYDV-RPV OH1 & MN241034 & $6.0 \times 10^{4}$ & 110 & L25299 & 99.8 & 98.9 \\
\hline CYDV-RPS OH1 & MK975889 & $5.0 \times 10^{3}$ & 16 & AF235168 & 99.2 & 82.4 \\
\hline WSMV-OH1 & MK975887 & $1.8 \times 10^{5}$ & 138 & AF511614 & 99.9 & 98.0 \\
\hline BMV-OH2 RNA 1 & MN241035 & $6.5 \times 10^{5}$ & 42 & X02380 & 98.1 & 98.8 \\
\hline BMV-OH2 RNA 2 & MN241136 & $5.4 \times 10^{5}$ & 154 & X01678 & 96.3 & 98.0 \\
\hline BMV-OH2 RNA 3 & MN241037 & $7.1 \times 10^{5}$ & 88 & J02042 & 99.5 & 98.9 \\
\hline WSSMV-OH1 RNA 1 & MN046367 & $2.1 \times 10^{5}$ & 80 & MH645041 & 99.8 & 99.2 \\
\hline WSSMV-OH1 RNA 2 & MN046368 & $1.2 \times 10^{5}$ & 41 & MH645042 & 93.6 & 98.4 \\
\hline WSSMV-OH2 RNA 1 & MN046369 & $1.2 \times 10^{4}$ & 5 & MH645041 & 99.9 & 93.4 \\
\hline WSSMV-OH2 RNA 2 & MN046370 & $8.0 \times 10^{3}$ & 2 & MH645042 & 30.3 & 93.0 \\
\hline SBWMV-OH2 RNA 1 & MN241032 & $7.8 \times 10^{3}$ & 1 & L07937 & 100 & 89.3 \\
\hline SBWMV-OH2 RNA 2 & MN241033 & $4.5 \times 10^{4}$ & 1 & L07938 & 100 & 90.5 \\
\hline ONMV-OH1 & MK975888 & $1.5 \times 10^{3}$ & 1 & AY377938 & 99.2 & 98.5 \\
\hline HPWMoV NWB1 RNA 1 & MN250337 & 192 & 1 & KJ939623 & 5.7 & 99.8 \\
\hline HPWMoV NWB1 RNA 2 & MN250338 & 839 & 6 & KJ939624 & 99.2 & 99.6 \\
\hline HPWMoV NWB1 RNA 3A & MN250339 & $1.8 \times 10^{3}$ & 11 & KJ939625 & 99.0 & 99.2 \\
\hline HPWMoV NWB1 RNA 3B & MN250340 & 283 & 11 & KJ939626 & 71.4 & 99.6 \\
\hline HPWMoV NWB1 RNA 4 & MN250341 & 475 & 3 & KJ939627 & 28.4 & 99.7 \\
\hline HPWMoV NWB1 RNA 5 & MN311483 & 963 & 1 & KJ939628 & 16.6 & 98.1 \\
\hline HPWMoV NWB1 RNA 6 & MN250342 & $1.8 \times 10^{3}$ & 7 & KJ939629 & 83.6 & 99.7 \\
\hline HPWMoV NWB1 RNA 7 & MN250343 & 743 & 9 & KJ939630 & 76.0 & 98.7 \\
\hline HPWMoV NWB1 RNA 8 & MN250344 & $1.2 \times 10^{3}$ & 15 & KJ939631 & 99.2 & 99.6 \\
\hline HPWMoV NWB2 RNA 1 & MN250345 & $4.9 \times 10^{3}$ & 24 & KJ939623 & $100.2^{\mathrm{h}}$ & 84.1 \\
\hline HPWMoV NWB2 RNA 2 & MN250346 & $1.5 \times 10^{4}$ & 2 & KJ939624 & 87.9 & 85.9 \\
\hline HPWMoV NWB2 RNA 3 & MN250347 & $6.8 \times 10^{4}$ & 9 & KJ939625 & 106.6 & 82.1 \\
\hline HPWMoV NWB2 RNA 4 & MN250348 & $2.2 \times 10^{4}$ & 10 & KJ939627 & 99.9 & 88.5 \\
\hline HPWMoV NWB2 RNA 5 & MN250349 & $1.2 \times 10^{4}$ & 12 & KJ939628 & 100.0 & 81.9 \\
\hline HPWMoV NWB2 RNA 6 & MN250350 & $9.8 \times 10^{3}$ & 4 & KJ939629 & 101.0 & 80.5 \\
\hline HPWMoV NWB2 RNA 7 & MN250351 & $2.2 \times 10^{4}$ & 12 & KJ939630 & 96.7 & 85.2 \\
\hline HPWMoV NWB2 RNA 8 & MN250352 & $4.9 \times 10^{4}$ & 1 & KJ939631 & 87.3 & 75.3 \\
\hline
\end{tabular}

a Ohio $(\mathrm{OH})$ isolate $=$ Consensus sequences were derived from supercontig assemblies (longer contigs constructed from de novo assembled contigs that were generated using reads from high-throughput sequencing). Virus sequences are as follows: barley yellow dwarf virus PAV and PAS (BYDV-PAV and BYDV-PAS), cereal yellow dwarf virus RPV and RPS (CYDV-RPV and CYDV-RPS), wheat streak mosaic virus (WSMV), Brome mosaic virus (BMV), wheat spindle streak mosaic virus (WSSMV), soilborne wheat mosaic virus (SBWMV), oat necrotic mottle virus (ONMV), and High Plains wheat mosaic virus (HPWMoV) "Nebraska-like" (NWB1) and "Ohio-like" (NWB2) strains (NWB means that the specific samples were collected at the Ohio Agricultural Research and Development Center Northwest Agricultural Research Station, near Custar, in Wood County).

${ }^{b}$ Accession number of each sequence in GenBank.

${ }^{c}$ RPK = reads per kilobase. The sums of all reads generated by high-throughput sequencing in 2012 and 2016 were mapped back to the consensus sequences using CLC Genomics Workbench "map reads to contigs" tool. The RPK depicted is the sum of the number of reads from all samples that mapped to the sequence/ number of kilobases in the sequence.

d Number of de novo assembled contigs that comprise the supercontig assembly.

e Type species accession = RNA sequence in GenBank for the type virus species

${ }^{\mathrm{f}}$ Coverage $=$ number of nucleotides (nt) in Ohio sequence/number of $\mathrm{nt}$ in species type isolate sequence.

g Percent nucleotide identity of the Ohio sequence to the species type isolate sequence.

${ }^{\mathrm{h}}$ Coverage of certain sequences of HPWMoV NWB2 exceeded 100\% compared with the type isolate because of the fact that the sequence of the Ohio-like strain was longer than the Nebraska-like strain, previously confirmed by Stewart (2016). 
near-complete sequences of RNA 1, 2, 3B, 4, 5, 6, 7, and 8 and a partial sequence of RNA 3A (MN250353 to MN250358, MN311485, MN311486, MN315362, MN315363) (Supplementary Table S5). The consensus sequences for each RNA segment of HPWMoV NWB1, HPWMoV MI, and HPWMoV ID shared 97.0 to $99.8 \%$ nucleotide identity to the HPWMoV Nebraska isolate complete genome (KJ929623 to KJ929631), which is also the HPWMoV type isolate.
From our surveys, eight near-complete genome segments of HPWMoV Ohio-like were assembled and deposited in GenBank as HPWMoV NWB2 (MN250345 to MN250352). The consensus sequences for each RNA segment of the Ohio-like isolate shared 96 to $99 \%$ nucleotide identity to the corresponding HPWMoV Ohio RNA reported previously (Stewart 2016). As reported before (Stewart 2016), no contigs that shared similarity to RNA segment

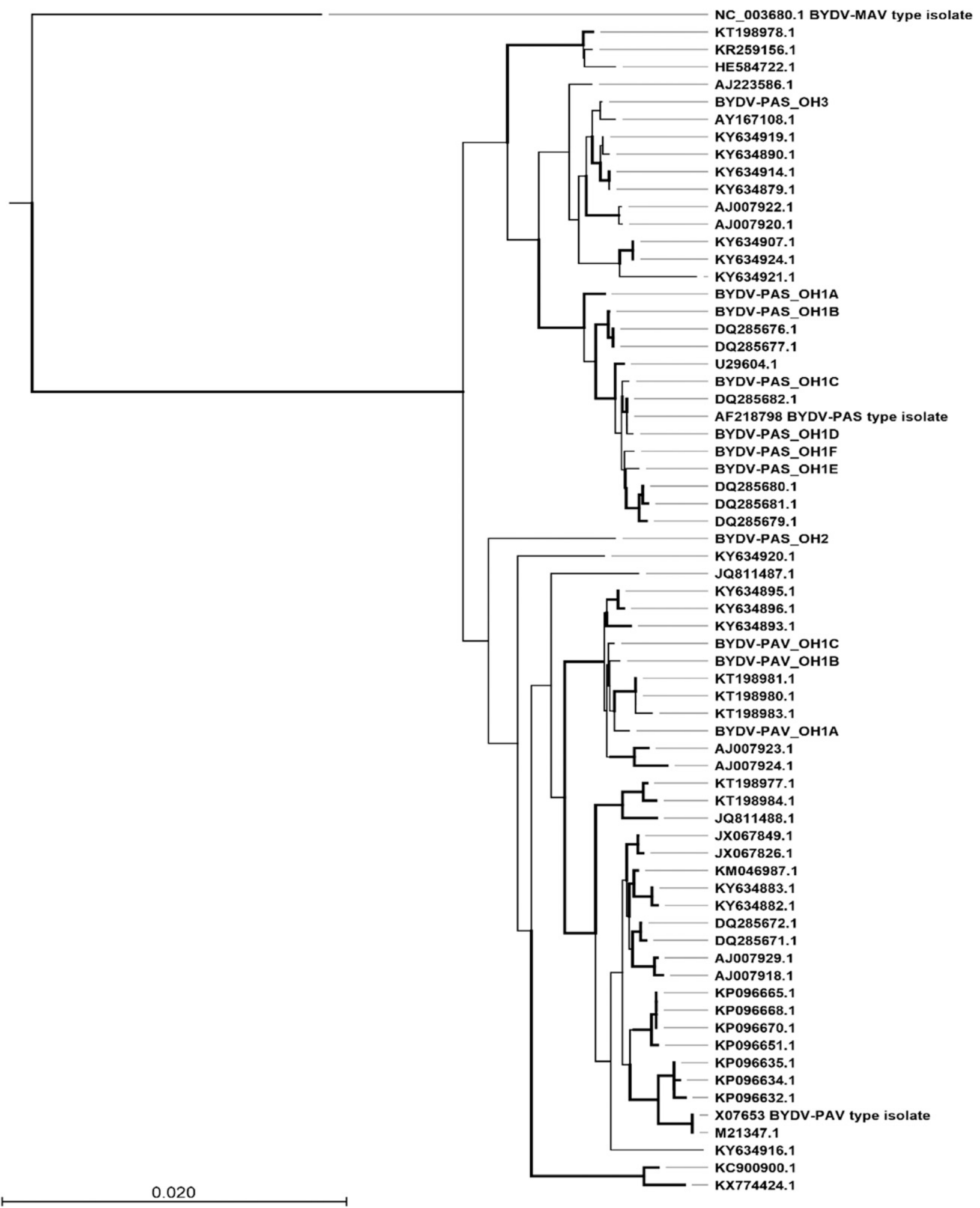

Fig. 3. Phylogram of maximum likelihood analysis with a GTR-gamma substitution model of barley yellow dwarf virus (BYDV) coat protein nucleotide sequences (603 bp) with 1,000 bootstrap replicates (bootstrap values $>70$ displayed as bold branches). All BYDV-PAV and BYDV-PAS coat protein sequences were downloaded from GenBank, and identical sequences were removed prior to the analysis. Type isolates of BYDV-PAV (X07653), BYDV-PAS (AF218798), and BYDV-MAV (NC_003680) were included to demonstrate clustering with Ohio isolates and other sequences. The BYDV-MAV sequence was used as an outgroup in the analysis and to root the phylogenetic tree. The scale bar represents the nucleotide substitution rate. 
3B of the Nebraska-like sequences were found in these isolates, even from the virion preparation sample. When compared with the HPWMoV type isolate from Nebraska (KJ939623 to KJ939631), each sequence shared 75.3 to $88.5 \%$ sequence identity with the corresponding RNA segment (Table 2).

SBWMV RNA 1 and 2 sequences were de novo assembled from the 2012 data and were deposited in GenBank as SBWMV-OH2 RNA 1 (MN241032) and SBWMV-OH2 RNA 2 (MN241033). Both sequences shared $>99 \%$ identity to the previously described SBWMV Ohio isolate (KT736088-9; Jarugula et al. 2016), and RNA 1 and RNA 2 of SBWMV-OH2 were 89.3 and $90.5 \%$ identical to the SBWMV type isolate RNA 1 and 2 sequences, respectively (L07937-8). SBWMV sequences were not detected in the 2016 dataset.

Additional viruses. One contig with similarity to ONMV was de novo assembled from the 2012 data and deposited in GenBank as ONMV-OH1 (MK975888). This contig shared 98.5\% nucleotide identity to ONMV-Nebraska (AY377938.1). CfMV and AgMV complete sequences were previously reported from the 2016 data (MF621330 to MF621333; Hodge et al. 2018a, b).

Virus presence is associated with field site-specific factors. Based on results from binary logistic regression analyses, each of the scored field factors had a statistically significant $(P \leq 0.10)$ association with the presence of at least one of the viruses for which analyses were run (Table 3). Volunteer wheat was associated with the presence of BYDV-PAV $(P=0.09)$, CYDV-RPV $(P=0.10)$, $\operatorname{WSSMV}(P=0.02)$, and WSMV $(P<0.01)$, with these viruses being respectively $2.3,2.1,2.8$, and 6.2 times more likely to be found in sites with adjacent volunteer wheat fields than in those without. BMV was 2.8 times more likely to be present in a site that was adjacent to a corn field $(P=0.08$, data not shown in Fig. 4) than in one without adjacent corn. Previous crop was associated with the presence of BYDV-PAV $(P=0.07)$, BYDV-PAS $(P=0.03)$, and CfMV $(P=0.09)$, with the odds of detecting these viruses being $2.2,3.8$, and 2.4 times greater, respectively, at sites where the wheat field was planted after a monocot than one planted after soybean.

Virus incidence within fields. To assess individual virus incidences at the field scale, samples were collected along diagonal transects within cultivated wheat fields and subjected to DAS-ELISA for BYDV-PAV, CYDV-RPV, WSMV, BMV, WSSMV, SBWMV, and HPWMoV in the 2016 and 2017 survey years. In 2016, WSSMV and WSMV had the highest mean incidence (number of samples virus was detected/20 samples collected per field) and the widest ranges of incidence among the viruses diagnosed (Fig. 5A). WSSMV incidence ranged from 5 to $100 \%$, with a mean incidence of $43.6 \%$ across 11 fields. WSMV incidence ranged from 5 to $75 \%$, with a mean of $23.7 \%$ across eight fields. BYDV-PAV and CYDV-RPV had similar mean incidences to WSMV, with a smaller range. BYDV-PAV mean incidence was $20 \%$ across 14 fields, with a range of 5 to $45 \%$. Similarly, the incidence of CYDV-RPV ranged from 5 to $50 \%$ across 22 fields, with a mean of $23 \%$. BMV, HPWMoV, and SBWMV were detected at the lowest means and ranges of incidence. BMV incidence ranged from 5 to $25 \%$, with a mean of $13.7 \%$ across four fields, whereas HPWMoV and SBWMV were detected at 5\% incidence in one field each.
In 2017, similar trends were observed. WSSMV mean incidence was $55 \%$ across seven fields, with a range of 20 to $100 \%$; WSMV mean incidence was $17 \%$ across seven fields, ranging from 5 to $65 \%$. BYDV-PAV incidence ranged from 5 to $25 \%$, with a mean
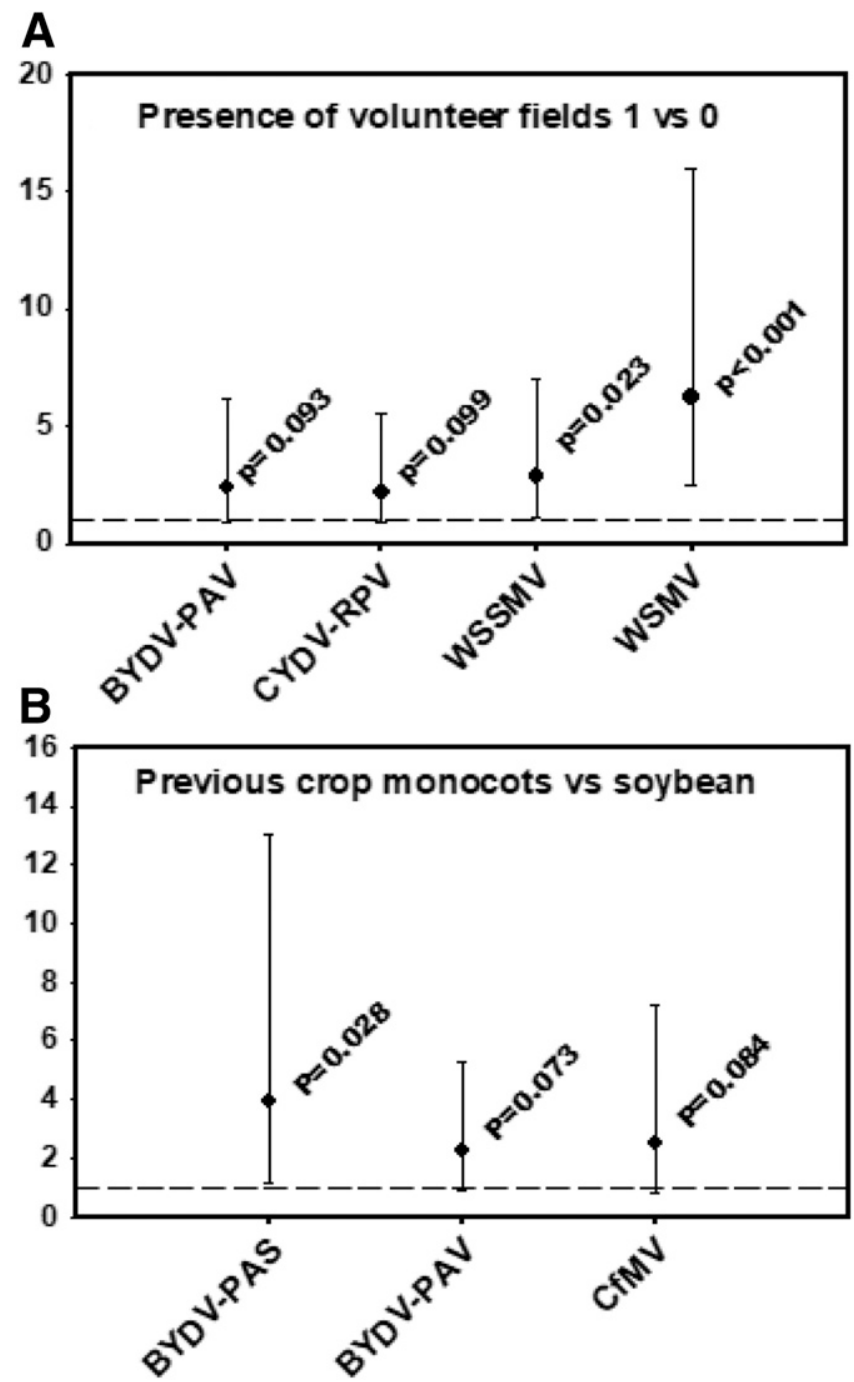

Fig. 4. Odds ratios (dots) and corresponding $95 \%$ confidence intervals (error bars) and probability values following binary logistic regression analysis of the association between field site-specific factors and the presence of specific viruses. For each explanatory variable tested, only the odds ratios and confidence intervals from significant $(P \leq 0.10)$ associations are plotted on the $y$-axis. For each panel, the odds ratio is a ratio of the odds of detecting the virus at the tested factor level (A, $1=$ volunteer wheat was present at the site; $\mathbf{B}$, monocot was the previous crop) relative to the odds of detecting it at the reference factor level $(0=$ volunteer was not present at the site; soybean was the previous crop). BYDV $=$ barley yellow dwarf virus, CYDV = cereal yellow dwarf virus, WSSMV = wheat spindle streak mosaic virus, and WSMV = wheat streak mosaic virus.

Table 3. Probability values (level of significance) from binary logistic regression analysis of associations between the presence of viruses in Ohio detected by reverse transcription PCR and field site-specific factors

\begin{tabular}{|c|c|c|c|c|c|c|c|}
\hline Site-specific factor ${ }^{a}$ & BMVb & BYDV-PAV & BYDV-PAS & CfMV & CYDV-RPV & WSSMV & WSMV \\
\hline Volunteer field & $\mathrm{NS}^{\mathrm{c}}$ & 0.093 & NS & NS & 0.099 & 0.023 & $<0.001$ \\
\hline Nearby corn & 0.081 & NS & NS & NS & NS & NS & NS \\
\hline Previous crop & NS & 0.073 & 0.028 & 0.094 & NS & NS & NS \\
\hline
\end{tabular}

a Volunteer field = a volunteer wheat field was observed at or adjacent to the site of tissue collection; nearby corn = a field of corn residue was observed next to the planted wheat field, indicating that corn was planted in that field the previous summer; and previous crop = previous crop planted in the cropping sequence before wheat, determined by the crop residue that was on the ground. The previous crop was grouped into monocots (corn, wheat, rye, oats, barley) and soybeans.

b Virus names are as follows: Brome mosaic virus (BMV), Barley yellow dwarf virus PAV and PAS (BYDV-PAV and BYDV-PAS), Cocksfoot mottle virus (CfMV), Cereal yellow dwarf virus RPV (CYDV-RPV), Wheat spindle streak mosaic virus (WSSMV), and Wheat streak mosaic virus (WSMV).

${ }^{c} \mathrm{NS}=$ not significant $(P>0.10)$. 
of $16 \%$ across 17 fields, and CYDV-RPV incidence ranged from 5 to $30 \%$, with a mean of $15 \%$ across 23 fields. BMV incidence was $5 \%$ in each of two fields, and SBWMV incidence was $5 \%$ in one field. HPWMoV incidence ranged from 5 to $15 \%$, with a mean incidence of $11.6 \%$ across three fields.

At the region level, incidence followed a similar trend, with means of 45.5, 4.2, 23.2, and 0\% for WSSMV in the Northeast, Northwest, Western, and South regions, respectively. The mean incidence of WSMV was $11.4,8.3,4.6$, and $5 \%$, respectively, in these same regions. BYDV-PAV mean incidences were 5.4, 7.2, 14.2, and 9\%, whereas mean incidences of CYDV-RPV were 15, 5.2, 20, and $11.5 \%$ in the corresponding four regions. BMV was only detected in the Northeast, Northwest, and Western regions at mean incidences of $2.8,2.0$, and $1.1 \%$, respectively. SBWMV mean incidence was $0.4 \%$ in both the Northwest and Western regions, and the mean incidence of HPWMoV was 1.5 and $1.1 \%$, respectively, in these same two regions.

Virus heterogeneity at multiple spatial scales. Estimated variances for incidence using generalized linear mixed model analysis are listed in Table 4. Based on these results, the estimated variance for incidence at the level of county within wheat growing region was significantly different from $0(P<0.05)$ for BMV, BYDVPAV, CYDV-RPV, HPWMoV, WSMV, and WSSMV, but not for SBWMV. Incidences of WSSMV and HPWMoV were the most heterogenous at the county level, both with an estimated incidence variance of 8.99. On the other hand, the estimated variances at the county level for both Luteoviridae viruses BYDV-PAV and CYDV-RPV were the lowest at 0.52 and 0.19 , respectively. Incidence was much less variable at the higher spatial scale. Variance at the wheat growing region level was significantly different from zero only for CYDV-RPV $(P=0.01)$, with an estimated value of 0.30 .

Meta-analyses were conducted on the results from the ordinary runs analyses to generate a global $P$ value for use as evidence of spatial clustering of samples testing positive for each virus within the transects. Statistically significant evidence of spatial clustering was indicated for BYDV-PAV, WSMV, and WSSMV, which all had a global $P$ value of $<0.001$.

\section{Discussion}

To address the paucity of contemporary information regarding viruses capable of affecting wheat production in Ohio, we used a combination of HTS, RT-PCR, and ELISA to identify viruses in Ohio wheat fields, assess their sequence diversity, and quantify virus prevalence, incidence, and spatial heterogeneity and clustering. Results from HTS analyses identified 12 viruses in Ohio wheat. Based on prevalence, incidence, and known biology, we grouped the viruses into three risk categories: high potential risk (B/CYDVs, WSMV, and WSSMV) (previous assessments of yield reduction described by Almas et al. 2016; Perry et al. 2000; and Slykhuis 1970), low potential risk (HPWMoV, AgMV, ONMV, and SBWMV) (Byamukama et al. 2013; Campbell et al. 1975; Gill 1967; Slykhuis 1962; Stewart et al. 2014), and unknown risk (BMV and CfMV) (Hodge et al. 2018a, 2019). Statistical analyses to assess virus variability at multiple spatial scales, spatial clustering, and associations with field properties were also performed.

Viruses in the family Luteoviridae, known to cause yield loss in wheat globally (Miller and Rasochova 1997), were most prevalent and diverse in Ohio wheat. Five species of BYDV and CYDV were found, with the highest sequence diversity among BYDV-PAS species. We consider BYDV-PAV and CYDV-RPV to be the luteovirids of greatest concern in the state, owing to their high prevalence, incidences, and documented negative yield impacts. A previous study demonstrated SRWW yield loss ranging from 27 to $45 \mathrm{~kg} / \mathrm{ha}$ for each $1 \%$ increase of BYDV-PAV incidence in susceptible cultivars in Indiana (Perry et al. 2000). By extrapolation, a $45 \mathrm{~kg} / \mathrm{ha}$ reduction per $1 \%$ increase in BYDV-PAV incidence might cause 225 to $2,250 \mathrm{~kg} / \mathrm{ha}$ and 225 to $1,350 \mathrm{~kg} / \mathrm{ha}$ yield reduction per field in Ohio in 2016 and 2017, respectively. Resistance to B/CYDVs was previously developed in the SRWW introgression line P29 (Sharma et al.
1995), completely resistant to CYDV-RPV, but only partially resistant to BYDV-PAV and BYDV-PAS (Anderson et al. 1998). There are currently no data available regarding the use of this resistance in modern SRWW cultivars grown in Ohio.

A novel variant of BYDV-PAS (BYDV-PAS OH2) was confirmed to be present in Ohio. These variants of BYDV-PAS and the Ohio isolate of CYDV-RPS (CYDV-RPS OH1) appear to be new species within their respective genera. CYDV-RPS OH1 and the highly similar Michigan isolate of CYDV-RPS (Malmstrom et al. 2017) are currently named CYDV-RPS; however, both are highly divergent from the type CYDV-RPS isolate and should likely be renamed as a separate species when further biological characterization is done. For BYDV-PAS OH2, open reading frames ORF 1 (RNA-dependent RNA polymerase) and ORF 3 (coat protein) are more than $10 \%$ divergent at the amino acid level from both the BYDV-PAV and BYDV-PAS type isolates, and the coat protein does not cluster in a monophyletic group with the coat proteins of either type isolate. Biological characterization including host range, vector specificity, pathogenicity, and serological specificity is needed for these viruses.

WSMV is a major pathogen of hard wheats, but its impact on SRWW wheat yield is not yet known. Ohio WSMV shared high sequence identity with other North American isolates and was detected in up to $75 \%$ of the wheat fields surveyed. In hard red winter wheat in Texas, $75 \%$ WSMV incidence led to 36 to $74 \%$ yield reduction (Almas et al. 2016). Resistance to WSMV conferred by the Wsm2
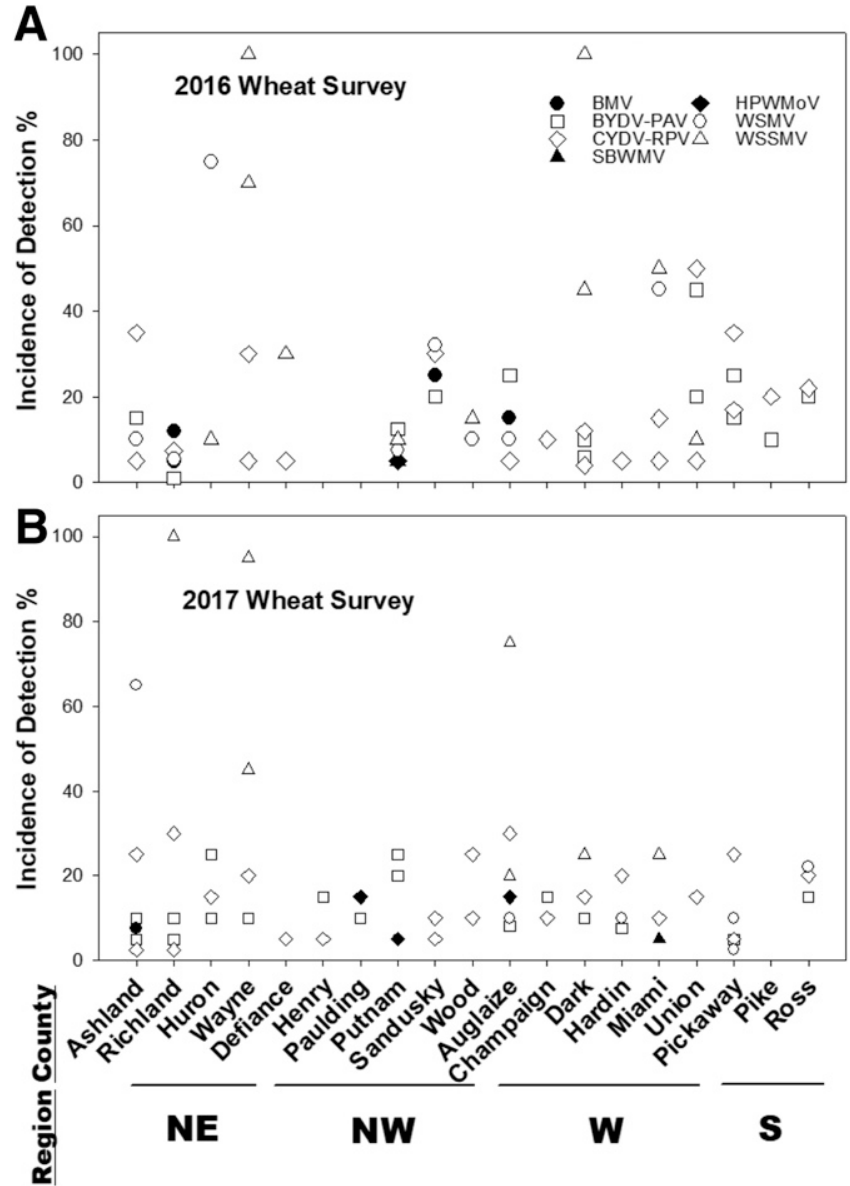

Fig. 5. Incidence of detection (number of samples in which the virus was detected by enzyme-linked immunosorbent assay divided by 20 , the total number of collected samples, multiplied by 100) for Brome mosaic virus (BMV), Barley yellow dwarf virus PAV (BYDV-PAV), Cereal yellow dwarf virus RPV (CYDV-RPV), Soilborne wheat mosaic virus (SBWMV), High Plains wheat mosaic virus (HPWMoV), Wheat streak mosaic virus (WSMV), and Wheat spindle streak mosaic virus (WSSMV) in 19 surveyed Ohio counties within four wheat growing regions (NE = Northeast, NW = Northwest, $W=$ Western, and $S=$ Southern; see map in Fig. 1) in 2016 and 2017. Each point on the graph represents incidence within a single wheat field. 
gene is available in hard red and white winter wheat (Haley et al. 2002, 2011); to our knowledge, there is no resistance available to WSMV in SRWW. Our findings suggest that the risk of WSMV yield loss in SRWW is high and merits priority examination.

This survey provides two of the first three complete or nearcomplete sequences of both RNA 1 and RNA 2 of WSSMV, confirming the recent submission of the complete genome sequence of this virus from France (MH645040 and MH645042). Only the coat protein-encoding sequence on RNA 1 was previously known. We identified two distinct variants of WSSMV in Ohio $(\mathrm{OH} 1$ and $\mathrm{OH} 2$ ), suggesting that further variability is likely. Further research is needed to determine whether the two variants differ in virulence or response to known resistance in SRWW (Haufler and Fulbright 1986). Our results and historical accounts (Jordan 1995; Lafever 1976) indicate that WSSMV may be endemic in Ohio. Incidences of WSSMV were high in 2016 and 2017, up to $100 \%$ in some fields. High incidences have also been reported in New York (Miller et al. 1991), but high incidence and prevalence does not always translate into significant yield impact. However, cool, wet conditions in late fall and during the spring are associated with severe yield reduction by WSSMV (Slykhuis 1970), and such conditions are common in Ohio.

Low prevalence viruses that we consider of lower risk to Ohio wheat include ONMV, HPWMoV, AgMV, and SBWMV. ONMV was only identified in 2012 when samples included weedy grasses and is not known to infect wheat (Gill 1967). SBWMV and AgMV were of similarly low prevalence. Two sequence strains of HPWMoV were first detected in Ohio in 2012 (Stewart 2016; Stewart et al. 2013), but this virus was not detected in the 2016 and 2017 surveys even though it shares a vector (wheat curl mite, Aceria tosichella) with the highly prevalent WSMV. HPWMoV isolates have been shown to have differential transmission by different collections of A. tosichella from different states (Seifers et al. 2002), but the transmission capabilities of Ohio wheat curl mites of Ohio HPWMoV strains and their differential pathology, if any, are not known and warrant further investigation.

BMV and CfMV were surprising to find in Ohio wheat fields. Before these surveys, BMV was not reported or expected to be a major pathogen in wheat. However, it was detected in all three surveys, with the highest prevalence in 2012 and maximum incidence of up to $25 \%$ within cultivated fields in the 2016 survey. A series of field experiments in Ohio demonstrated that BMV infection caused yield reduction in SRWW of up to $61 \%$ from early growth stage infections and 25 to $36 \%$ when infection occurred at Feekes stage 5, 8, or 10 (Hodge et al. 2019), demonstrating significant pathogenic potential and potentially high risk. However, field transmission and factors associated with yearly fluctuation in the prevalence of this virus are unknown. In the case of CfMV, it was first reported in the United States in Oregon in 2015 (Alderman et al. 2016) and through our survey was first detected in two field sites in Ohio in 2016 (Hodge et al. 2018a). CfMV was again detected at 17 sites in 2017, suggesting that further monitoring in Ohio and potentially the United States is needed (Hodge et al. 2018a).

In this study, logistic regression analyses were valuable for identifying potential risk factors associated with virus presence and, as such, provided insights as to potential management strategies for further investigation. Volunteer wheat fields were associated with the presence of BYDV-PAV, BYDV-PAS, CYDV, WSSMV, and WSMV. This is not surprising because volunteer wheat is a well-known virus reservoir, especially for B/CYDVs and WSMV (Christian and Willis 1993; Hawkes and Jones 2005). For WSSMV, symptom development was reported to be more likely in cultivated fields where wheat was planted the previous year or continuously (Carroll et al. 2002; Slykhuis 1970), reflecting the persistence of this virus and its vector in the soil (Slykhuis and Barr 1978). The association of previous monocot crops with the presence of BYDV-PAV, BYDVPAS, and CfMV was surprising, however, as previous crop is not known to play a role in the epidemiology of these viruses. In most cases, the monocot that was planted prior to wheat was corn, with only a few exceptions in which the previous crops were wheat, oats, or rye. An association was also observed between the presence of adjacent corn field and the presence of BMV. These associations may indicate that corn may play a role in the infection cycle, perhaps as a host for these viruses or their vectors. Indeed, Brown et al. (1984) described irrigated corn in Washington as an oversummering host for BYDV-PAV and its vector $R$. padi, leading to early infection of winter wheat. Previous work demonstrated that BYDV (species unknown) can infect U.S. corn cultivars (Stoner 1977) and BMV-OH can infect sweet corn (Hodge et al. 2019). Further investigation is needed to determine whether corn is a host for Ohio BYDV, BMV, or CfMV.

We used virus incidence data to characterize the heterogeneity of viruses at multiple spatial scales. Hughes et al. (1997) also estimated the variance of virus incidence at multiple spatial scales, but the approach used was quite different. The high variability of incidence of most of the viruses investigated at the county scale suggests that there were county-specific factors influencing virus incidence. Management of viruses with higher county-level heterogeneity could target factors such as cropping practices that are likely more variable between counties. Conversely, only the incidence of CYDV-RPV was variable at both the county and Ohio regional spatial scales, suggesting that incidence was influenced by both regional-specific factors, such weather conditions, as well as county-level factors like cropping practices. The fact that CYDV-RPV was influenced by regional factors but BYDV-PAV was not is surprising, as these two viruses are both transmitted by $R$. padi and are typically managed together as parts of the barley yellow dwarf complex (Miller and Rasochova 1997; Power and Gray 1995). Our results could indicate that

Table 4. Estimated mean incidence for the most prevalent viruses across field sites on the logit $(\beta)$ and original data scale $(p)$, estimated variances $\left(\hat{\sigma}_{R}^{2}\right.$ and $\left.\hat{\sigma}_{C}^{2}\right)$, and corresponding SEs and probability values following generalized linear mixed model analysis of the random effects of wheat growing region and county within wheat growing region on virus incidence in cultivated wheat fields in 2016 and 2017

\begin{tabular}{|c|c|c|c|c|c|c|}
\hline \multirow[b]{2}{*}{ Virus } & \multirow[b]{2}{*}{$\boldsymbol{\beta} \pm \mathrm{SE}$} & \multirow[b]{2}{*}{$p \pm \mathrm{SE}$} & \multicolumn{2}{|c|}{ Wheat growing region ${ }^{a}$} & \multicolumn{2}{|c|}{ County (region) $)^{\mathbf{b}}$} \\
\hline & & & $\hat{\boldsymbol{\sigma}}_{R}^{2}$ & $P^{\mathbf{c}}$ & $\hat{\boldsymbol{\sigma}}_{C}^{2}$ & $P$ \\
\hline $\mathrm{BMV}$ & $-6.43 \pm 1.3$ & $0.1 \pm 0.2$ & $\mathrm{NS}^{\mathrm{d}}$ & $>0.999$ & $4.53 \pm 2.4$ & 0.005 \\
\hline BYDV-PAV & $-2.91 \pm 0.2$ & $5.1 \pm 1.0$ & NS & $>0.999$ & $0.52 \pm 0.30$ & $<0.001$ \\
\hline CYDV-RPV & $-2.46 \pm 0.2$ & $7.8 \pm 1.4$ & $0.30 \pm 0.27$ & 0.010 & $0.19 \pm 0.15$ & 0.020 \\
\hline SBWMV & $-6.59 \pm 0.7$ & $0.1 \pm 0.0$ & NS & $>0.999$ & NS & $>0.999$ \\
\hline HPWMoV & $-4.49 \pm 1.0$ & $1.1 \pm 1.0$ & NS & $>0.999$ & $8.99 \pm 4.8$ & $<0.001$ \\
\hline WSMV & $-4.11 \pm 0.5$ & $1.6 \pm 0.7$ & NS & $>0.999$ & $2.60 \pm 1.4$ & $<0.001$ \\
\hline WSSMV & $-4.50 \pm 0.9$ & $1.1 \pm 1.0$ & NS & $>0.999$ & $8.99 \pm 4.8$ & $<0.001$ \\
\hline
\end{tabular}

a Wheat-growing region = estimates of variance $\left(\hat{\sigma}_{R}^{2}\right)$ and probability values for mean virus incidence between the various wheat growing regions that were sampled in Ohio, which included the Northwest, Northeast, Western, and Southern regions (see map in Fig. 1).

${ }^{\mathrm{b}}$ County (region) $=$ estimates of variance $\left(\hat{\sigma}_{C}^{2}\right)$ and probability values for mean virus incidence between the counties within regions.

${ }^{\mathrm{c}} \alpha=0.05$.

$\mathrm{d}$ The estimated variance for nonsignificant values (NS) is 0 . 
CYDV-RPV was influenced by factors that did not affect BYDV, which could be an important consideration for management.

Line transect data were used to test for evidence of in-field virus clustering, providing valuable information regarding virus biology that is useful for management. For arthropod-vectored viruses like BYDV-PAV and WSMV, clustering can indicate that secondary spread (spread from initially infected plants to disease-free plants within a field) occurred (Madden et al. 1982). In our surveys, tissues were collected in early spring when temperatures and insect populations were low, suggesting that infections likely began in the fall. These findings would therefore support the implementation of management strategies that minimize fall infections. Notably, BYDVPAV showed evidence of clustering but CYDV-RPV did not, further supporting our hypothesis that there may be factors influencing the distribution of these two viruses other than the vector they share. For WSSMV, our evidence of an aggregated spatial pattern supports reports from a study by Slykhuis (1970) that documented the occurrence of WSSMV in large patches or an entire field. Findings from these analyses can be used to develop sampling protocols to monitor these diseases and further investigate factors affecting virus distribution.

Our survey results provide a catalog of viruses in Ohio wheat, their incidence, prevalence, and sequence variation, and statistical associations with field site factors. Based on these results, we grouped the viruses identified into risk categories and suggest further research avenues based on unknown of virus biology and statistical associations. Our results provide an extensive framework from which to formulate such future work.

\section{Acknowledgments}

We thank the Ohio county extension educators and Ohio wheat growers for providing access to wheat fields, members of the Paul and Stewart laboratories for their contributions to tissue and data collection, and Saranga Wijeratne and the Molecular Cellular Imaging Center for assistance with HTS data analysis.

\section{Literature Cited}

Alderman, S. C., Martin, R. C., Gilmore, B. S., Martin, R. R., Hoffman, G. D., Sullivan, C. S., and Anderson, N. P. 2016. First report of Cocksfoot mottle virus infecting Dactylis glomerata in Oregon and the United States. Plant Dis. 100:1030

Allison, P. D. 2012. Logistic Regression Using the SAS System: Theory and Application. SAS Institute Inc., Cary, NC.

Almas, L. K., Price, J. A., Workneh, F., and Rush, C. M. 2016. Quantifying economic losses associated with levels of wheat streak mosaic incidence and severity in the Texas High Plains. Crop Prot. 88:155-160.

Anderson, J. M., Bucholtz, D. L., Greene, A. E., Francki, M. G., Gray, S. M., Sharma, H., Ohm, H. W., and Perry, K. L. 1998. Characterization of wheatgrass-derived barley yellow dwarf virus resistance in a wheat alien chromosome substitution line. Phytopathology 88:851-855.

Barker, D., Culman, S., Dorrance, A., Fulton, J., Haden, R., Lentz, E., Lindsey, A., Lindsey, L., Loux, M., McCoy, E., Michel, A., Noel, J., Paul, P., Sulc, M., Thomison, P., Tilmon, K., and Witter, J. 2017. Ohio Agronomy Guide, 15th ed. The Ohio State University Bulletin 472. The Ohio State University, Columbus.

Basu, P. K., Lin, C. S., and Binns, M. R. 1977. A comparison of sampling methods for surveying alfalfa foliage diseases. Can. J. Plant Sci. 57:1091-1097.

Bockus, W. W., Appel, J. A., Bowden, R. L., Fritz, A. K., Gill, B. S., Martin, T. J., Sears, R. G., Seifers, D. L., Brown-Guedira, G. L., and Eversmeyer, M. G. 2001. Success stories: Breeding for wheat disease resistance in Kansas. Plant Dis. 85:453-461.

Borenstein, M., Hedges, L. V., Higgins, J. P. T., and Rothstein, H. R. 2009. Introduction to Meta-Analysis. John Wiley \& Sons, Chichester, UK.

Bowen, K. L., Murphy, J. F., Flanders, K. L., Mask, P. L., and Li, R. 2003. Incidence of viruses infecting winter wheat in Alabama. Plant Dis. 87:288-293.

Brakke, M. K. 1987. Virus diseases of wheat. Pages 585-624 in: Wheat and Wheat Improvement. Agronomy Monograph 13. American Society of Agronomy/ Crop Science Society of America /Soil Science Society of America, Madison, WI.

Brown, J. K., Wyatt, S. D., and Hazelwood, D. 1984. Irrigated corn as a source of barley yellow dwarf virus and vector in eastern Washington. Phytopathology 74:46-49.

Bruehl, G. W., and Keifer, H. H. 1958. Observations on wheat streak mosaic in Washington, 1955-1957. Plant Dis. Rep. 42:32-35.

Budge, G. E., Ratti, C., Rubies-Autonell, C., Lockley, D., Bonnefoy, M., Vallega, V., Pietravalle, S., and Henry, C. M. 2008. Response of UK winter wheat cultivars to Soil-borne cereal mosaic and Wheat spindle streak mosaic viruses across Europe. Eur. J. Plant Pathol. 120:259-272.
Burrows, M., Franc, G., Rush, C., Blunt, T., Ito, D., Kinzer, K., Olson, J., O’Mara, J., Price, J., Tande, C., and Ziems, A. 2009. Occurrence of viruses in wheat in the Great Plains region, 2008. Plant Health Prog. 10:14.

Byamukama, E., Seifers, D. L., Hein, G. L., De Wolf, E., Tisserat, N. A., Langham, M. A. C., Osborne, L. E., Timmerman, A., and Wegulo, S. N. 2013. Occurrence and distribution of Triticum mosaic virus in the central Great Plains. Plant Dis. 97:21-29.

Byamukama, E., Tatineni, S., Hein, G., McMechan, J., and Wegulo, S. N. 2016. Incidence of Wheat streak mosaic virus, Triticum mosaic virus, and Wheat mosaic virus in wheat curl mites recovered from maturing winter wheat spikes. Plant Dis. 100:318-323.

Byamukama, E., Wegulo, S. N., Tatineni, S., Hein, G. L., Graybosch, R. A., Baenziger, P. S., and French, R. 2014. Quantification of yield loss caused by Triticum mosaic virus and Wheat streak mosaic virus in winter wheat under field conditions. Plant Dis. 98:127-133.

Campbell, L. G., Heyne, E. G., Gronau, D. M., and Niblett, C. 1975. Effect of soilborne wheat mosaic virus on wheat yield. Plant Dis. Rep. 59:472-476.

Campbell, L. G., and Lefever, H. N. 1977. Cultivar by environment interactions in soft red winter wheat yield tests. Crop Sci. 17:604-608.

Carroll, J. E., Bergstrom, G. C., and Gray, S. M. 2002. Assessing the resistance of winter wheat to wheat spindle streak mosaic bymovirus. Can. J. Plant Pathol. 24:465-470.

Choudhury, S., Larkin, P., Meinke, H., Hasanuzzaman, M. D., Johnson, P., and Zhou, M. 2019. Barley yellow dwarf virus infection affects physiology, morphology, grain yield and flour pasting properties of wheat. Crop Pasture Sci. 70:16-25.

Christian, M. L., and Willis, W. G. 1993. Survival of wheat streak mosaic virus in grass hosts in Kansas from wheat harvest to fall wheat emergence. Plant Dis. 77: 239-242.

Clover, G. R., Ratti, C., and Henry, C. M. 2001. Molecular characterization and detection of European isolates of Soil-borne wheat mosaic virus. Plant Pathol. 50:761-767.

Cunfer, B. M., Demski, J. W., and Bays, D. C. 1988. Reduction in plant development, yield, and grain quality associated with wheat spindle streak mosaic virus. Phytopathology 78:198-204.

Derr, R. E. 2013. Pages 1-20 in: Ordinal response modeling with the LOGISTIC procedure. In: Proceedings of the SAS Global Forum 2013 Conference. SAS Institute Inc., Cary, NC.

Dutilh, B. E., Reyes, A., Hall, R. J., and Whiteson, K. L. 2017. Editorial: Virus discovery by metagenomics: The (im)possibilities. Front. Microbiol. 8:1710.

Elliott, P., and Wartenberg, D. 2004. Spatial epidemiology: Current approaches and future challenges. Environ. Health Perspect. 112:998-1006.

Folke, J. 1945. Epiphytology of winter wheat mosaic. Ohio J. Sci. 45:85-96.

Gbur, E. E., Stroup, W. W., McCarter, K. S., Durham, S., Young, L. J., Christman, M., West, M., and Kramer, W. 2012. Analysis of generalized linear mixed models in the agricultural and natural resource sciences. Crop Science Society of America, Madison, WI

Gibbons, J. D. 1976. Tests for Randomness. Pages 356-371 in: Nonparametric Methods for Quantitative Analysis. Holt, Rinehart, and Winston, New York, NY.

Gill, C. C. 1967. Oat necrotic mottle virus: A new virus disease in Manitoba. Phytopathology 57:302.

Green, A. J., Berger, G., Griffey, C. A., Pitman, R., Thomason, W., and Balota, M. 2012. Genetic yield improvement in soft red winter wheat in the eastern United States from 1919 to 2009. Crop Sci. 52:2097-2108.

Green, M., and Sambrook, J. 2012. Molecular Cloning: A Laboratory Manual. Cold Spring Harbor Laboratory Press, Cold Spring Harbor, New York.

Halbert, S. E., and Pike, K. S. 1985. Spread of barley yellow dwarf virus and relative importance of local aphid vectors in central Washington. Ann. Appl. Biol. 107:387-395

Haley, S. D., Johnson, J. J., Peairs, F. B., Stromberger, J. A., Heaton, E. E., Seifert S. A., Kottke, R. A., Rudolph, J. B., Martin, T. J., Bai, G., and Chen, X. 2011 Registration of 'Snowmass' wheat. J. Plant Regist. 5:87-90.

Haley, S. D., Martin, T. J., Quick, J. S., Seifers, D. L., Stromberger, J. A., Clayshulte, S. R., Clifford, B. L., Peairs, F. B., Rudolph, J. B., Johnson, J. J., and Gill, B. S. 2002. Registration of CO960293-2 wheat germplasm resistant to Wheat streak mosaic virus and Russian wheat aphid. Crop Sci. 42 1381-1383.

Hamm, P. B., Gieck, S. L., David, N. L., and Hunger, R. M. 2007. First report of Soilborne wheat mosaic virus on wheat (Triticum aestivum) in the Columbia Basin of Oregon. Plant Dis. 91:1513.

Haufler, K. Z., and Fulbright, D. W. 1986. Identification of winter wheat cultivars and experimental lines resistant to wheat spindle streak mosaic virus. Plant Dis. 70:31-33.

Hawkes, J. R., and Jones, R. A. C. 2005. Incidence and distribution of Barley yellow dwarf virus and Cereal yellow dwarf virus in over-summering grasses in a Mediterranean-type environment. Aus. J. Ag. Res. 56:257-270.

Himmel, P. T., Simmons, F. W., Hewings, A. D., and Glawe, D. A. 1992. Effects of soil water status on infection of soft red winter wheat by soilborne wheat mosaic virus. Can. J. Plant Pathol. 14:147-151.

Hodge, B., Paul, P., and Stewart, L. 2018a. First report of Cocksfoot mottle virus infecting wheat (Triticum aestivum) in Ohio. Plant Dis. 102:464.

Hodge, B., Paul, P., and Stewart, L. 2018b. Agropyron mosaic virus detection in Ohio wheat (Triticum aestivum). Plant Dis. 102:463. 
Hodge, B., Salgado, J., Paul, P., and Stewart, L. 2019. Characterization of an Ohio isolate of brome mosaic virus and its impact on the development and yield of soft red winter wheat. Plant Dis. 103:1101-1111.

Hollandbeck, G. F., DeWolf, E., and Todd, T. 2017. Kansas Cooperative Plant Disease Survey Report: Preliminary 2017 Kansas Wheat Disease Loss Estimates. https://agriculture.ks.gov/docs/default-source/pp-disease-reports2012/2017-ks-wheat-disease-loss-estimates.pdf?sfvrsn=ce1382c10

Hughes, G., McRoberts, N., Madden, L. V., and Gottwald, T. R. 1997. Relationships between disease incidence at two levels in a spatial hierarchy. Phytopathology 87:542-550.

International Committee on Taxonomy of Viruses. 2011. ICTV Ninth Report: Luteoviridae. ICTV, Leiden, Netherlands.

Jarugula, S., Charlesworth, S., Qu, F., and Stewart, L. 2016. Soil-borne wheat mosaic virus infectious clone and manipulation for gene-carrying capacity. Arch. Virol. 161:2291-2297.

Jordan, D. M. 1995. Ohio Wheat Performance Test. The Ohio Agricultural Research and Development Center Horticulture and Crop Science Series 228. The Ohio Agricultural Research and Development Center, Wooster, OH.

Kriss, A. B., Paul, P. A., and Madden, L. V. 2012. Characterizing heterogeneity of disease incidence in a spatial hierarchy: A case study from a decade of observations of fusarium head blight of wheat. Phytopathology 102:867-877.

Lafever, H. N. 1976. Ruler soft red winter wheat. The Ohio Agricultural Research and Development Center Research Circular 218. The Ohio Agricultural Research and Development Center, Wooster, $\mathrm{OH}$.

Large, E. C. 1954. Growth stages in cereals illustration of the Feekes scale. Plant Pathol. 3:128-129.

Lister, R. M., and Ranieri, R. 1995. Distribution and economic importance of barley yellow dwarf. Pages 29-53 in: Barley Yellow Dwarf 40 Years of Progress. C. J. D'Arcy and P. Burnett, eds. American Phytopathological Society, St. Paul, MN.

Lommel, S. A., Willis, W. G., and Kendall, T. L. 1986. Identification of wheat spindle streak mosaic virus and its role in a new disease of winter wheat in Kansas. Plant Dis. 70:964-968.

Louie, R., and Knoke, J. 1991. Detection of maize dwarf mosaic onset in Ohio. Phytopathology 81:760-765.

Louie, R., Siefers, D. L., and Bradfute, O. E. 2006. Isolation, transmission, and purification of the High Plains virus. J. Virol. Methods 135:214-222.

Madden, L., Louie, R., Abt, J., and Knoke, J. 1982. Evaluation of tests of randomness of infected plants. Phytopathology 72:195-198.

Maliogka, V., Minafra, A., Saldarelli, P., Ruiz-García, A., Glasa, M., Katis, N., and Olmos, A. 2018. Recent advances on detection and characterization of fruit tree viruses using high-throughput sequencing technologies. Viruses 10:436.

Malmstrom, C., and Shu, R. 2004. Mutliplexed RT-PCR for streamlined detection and separation of barley and cereal yellow dwarf viruses. J. Virol. Methods 120: $69-78$

Malmstrom, C. M., Bigelow, P., Trebicki, P., Busch, A. K., Friel, C., Cole, E., Abdel-Azim, H., Phillippo, C., and Alexander, H. M. 2017. Crop-associated virus reduces the rooting depth of non-crop perennial native grass more than non-crop-associated virus with known viral suppressor of RNA silencing (VSR). Virus Res. 241:172-184.

Mayer, K., Rogers, J., Dolezel, J., Pozniak, C., Eversole, K., and Feuillet, C. 2014. A chromosome-based draft sequence of the hexaploid bread wheat (Triticum aestivum) genome. Science 345:1251788

Miller, M., Pfeiffer, W., and Schwartz, T. 2010. Creating the CIPRES Science Gateway for inference of large phylogenetic trees. Pages 1-8 in: Proceedings of the Gateway Computing Environments Workshop; 14 November 2010; New Orleans, LA. IEEE, Piscataway, NJ.

Miller, N. R., Bergstrom, G. C., and Gray, S. M. 1991. Identity, prevalence and distribution of viral diseases of winter wheat in New York in 1988 and 1989. Plant Dis. 75:1105-1109.

Miller, W. A., and Rasochova, L. 1997. Barley yellow dwarf viruses. Annu. Rev. Phytopathol. 35:167-190.

Montarry, J., Doumayrou, J., Simon, V. and Moury, B. 2011. Genetic background matters: A plant-virus gene-for-gene interaction is strongly influenced by genetic contexts. Mol. Plant Pathol. 12:911-920.

National Agricultural Statistics Service. 2019. Ohio State 2018 Agricultural Overview. https://www.nass.usda.gov/Quick_Stats/Ag_Overview/stateOverview.php? state $=\mathrm{OHIO}$

Ohsato, S., Miyanishi, M., and Shirako, Y. 2003. The optimal temperature for RNA replication in cells infected by Soil-borne wheat mosaic virus is $17{ }^{\circ} \mathrm{C}$. J. Gen. Virol. 84:995-1000.

Ordon, F., Habekuss, A., Kastirr, U., Rabenstein, F., and Kühne, T. 2009. Virus resistance in cereals: Sources of resistance, genetics and breeding. J. Phytopathol. 157:535-545

Paul, P. A., and Munkvold, G. P. 2004. A model-based approach to preplanting risk assessment for grey leaf spot of maize. Phytopathology 94:1350-1357.
Perry, K. L., Kolb, F. L., Sammons, B., Lawson, C., Cisar, G., and Ohm, H. 2000 Yield effects of barley yellow dwarf virus in soft red winter wheat. Phytopathology 90:1043-1048.

Power, A. G., and Gray, S. M. 1995. Aphid transmission of barley yellow dwarf viruses: Interactions between viruses, vectors, and host plants. Pages 259 to 289 in: Barley Yellow Dwarf: 40 Years of Progress. C. D'Arcy and P. Burnett, eds. American Phytopathological Society, St. Paul, MN

Rao, A. S., and Brakke, M. K. 1969. Relation of soil-borne wheat mosaic virus and its fungal vector, Polymyxa graminis. Phytopathology 59:581-587.

Rotenberg, D., Bockus, W. W., Whitfield, A. E., Hervey, K., Baker, K. D., Ou, Z., Laney, A. G., De Wolf, E. D., and Appel, J. A. 2016. Occurrence of viruses and associated grain yields of paired symptomatic and nonsymptomatic tillers in Kansas winter wheat fields. Phytopathology 106:202-210.

Seifers, D. L., Harvey, T. L., Louie, R., Gordon, D. T., and Martin, T. J. 2002 Differential transmission of isolates of the High Plains virus by different sources of wheat curl mites. Plant Dis. 86:138-142

Sharma, H., Ohm, H., Goulart, L., Lister, R., Appels, R., and Benlhabib, O. 1995. Introgression and characterization of barley yellow dwarf virus resistance from Thinopyrum intermedium into wheat. Genome 38:406-413.

Shepherd, R. J., Richins, R. D., Duffus, J. E., and Handley, M. K. 1987. Figwort mosaic virus: Properties of the virus and its adaption to a new host Phytopathology 77:1668-1673.

Simon, A. C., Lopez-Nicora, H. D., Lindsey, L. E., Niblack, T. L., and Paul, P. A 2018a. Incidence, population density, and spatial heterogeneity of plantparasitic nematodes in corn fields in Ohio. Plant Dis. 102:2453-2464.

Simon, A. C. M., Lopez-Nicora, H. D., Niblack, T. L., Dayton, E. A. Tomashefski, D., and Paul, P. A. 2018b. Cropping practices and soil properties associated with plant-parasitic nematodes in corn fields in Ohio. Plant Dis. 102:2519-2530.

Singh, K., Wegulo, S. N., Skoracka, A., and Kundu, J. K. 2018. Wheat streak mosaic virus: A century old virus with rising importance worldwide. Mol. Plant Pathol. 19:2193-2206.

Slykhuis, J. T. 1962. Agropyron mosaic as a disease of wheat in Canada. Can. J. Bot. 40:1439-1447.

Slykhuis, J. T. 1970. Factors determining the development of wheat spindle streak mosaic caused by a soil-borne virus in Ontario. Phytopathology 60: 319-331.

Slykhuis, J. T., and Barr, D. J. S. 1978. Confirmation of Polymyxa graminis as a vector of wheat spindle streak mosaic virus. Phytopathology 68:639-643.

Stamatakis, A. 2014. RAxML version 8. A tool for phylogenetic analysis and postanalysis of large phylogenies. Bioinformatics 30:1312-1313.

Stenger, D. C., Seifers, D. L., and French, R. 2002. Patterns of polymorphism in Wheat streak mosaic virus: Sequence space explored by a clade of closely related viral genotypes rivals that between the most divergent strains. Virology 302:58-70.

Stewart, L. 2016. Sequence diversity of wheat mosaic virus isolates. Virus Res. 213:299-303.

Stewart, L., Paul, P., Qu, F., Redinbaugh, M. G., Miao, H., Todd, J., and Jones, M 2013. Wheat mosaic virus (WMoV), the causal agent of High Plains disease, is present in Ohio wheat fields. Plant Dis. 97:1125

Stewart, L., Teplier, R., Todd, J., Jones, M., Cassone, B., Wijeratne, S., Wijeratne, A., and Redinbaugh, M. G. 2014. Viruses in maize and Johnsongrass in southern Ohio. Phytopathology 104:1360-1369.

Stoner, W. N. 1977. Barley yellow dwarf virus infection in maize. Phytopathology 67:975-981.

Stroup, W. 2013. Generalized Linear Mixed Models: Modern Concepts, Methods, and Applications. Taylor and Francis Group, Boca Raton, FL.

Swed, F., and Eisenhart, C. 1943. Tables for testing randomness of grouping in a sequence of alternatives. Ann. Math. Stat. 14:66-87.

Tatineni, S., McMechan, A. J., Wosula, E. N., Wegulo, S. N., Graybosch, R. A., French, R., and Hein, G. L. 2014. An eriophyid mite-transmitted plant virus contains eight genomic RNA segments with unusual heterogeneity in the nucleocapsid protein. J. Virol. 88:11834-11845.

Todd, J. C., Ammar, E. D., Redinbaugh, M. G., Hoy, C., and Hogenhout, S. A 2010. Plant host range and leafhopper transmission of maize fine streak virus. Phytopathology 100:1138-1145

Velandia, M., Rejesus, R. M., Jones, D. C., Price, J. A., Workneh, F., and Rush, C. M. 2010. Economic impact of Wheat streak mosaic virus in the Texas High Plains. Crop Prot. 29:699-703.

Villamor, D. E., Ho, T., Al Rwahnih, M., Martin, R. R., and Tzanetakis, I. 2019. High throughput sequencing in plant virus detection and discovery. Phytopathology 109:716-725.

Voller, A., Bartlett, A., and Bidwell, D. E. 1978. Enzyme immunoassays with special reference to ELISA techniques. J. Clin. Pathol. 31:507-520.

Zambrano, J., Stewart, L., and Paul, P. 2016. Barley Yellow Dwarf of Wheat, Oats, and Barley. Ohio State University Extension, Columbus. 